
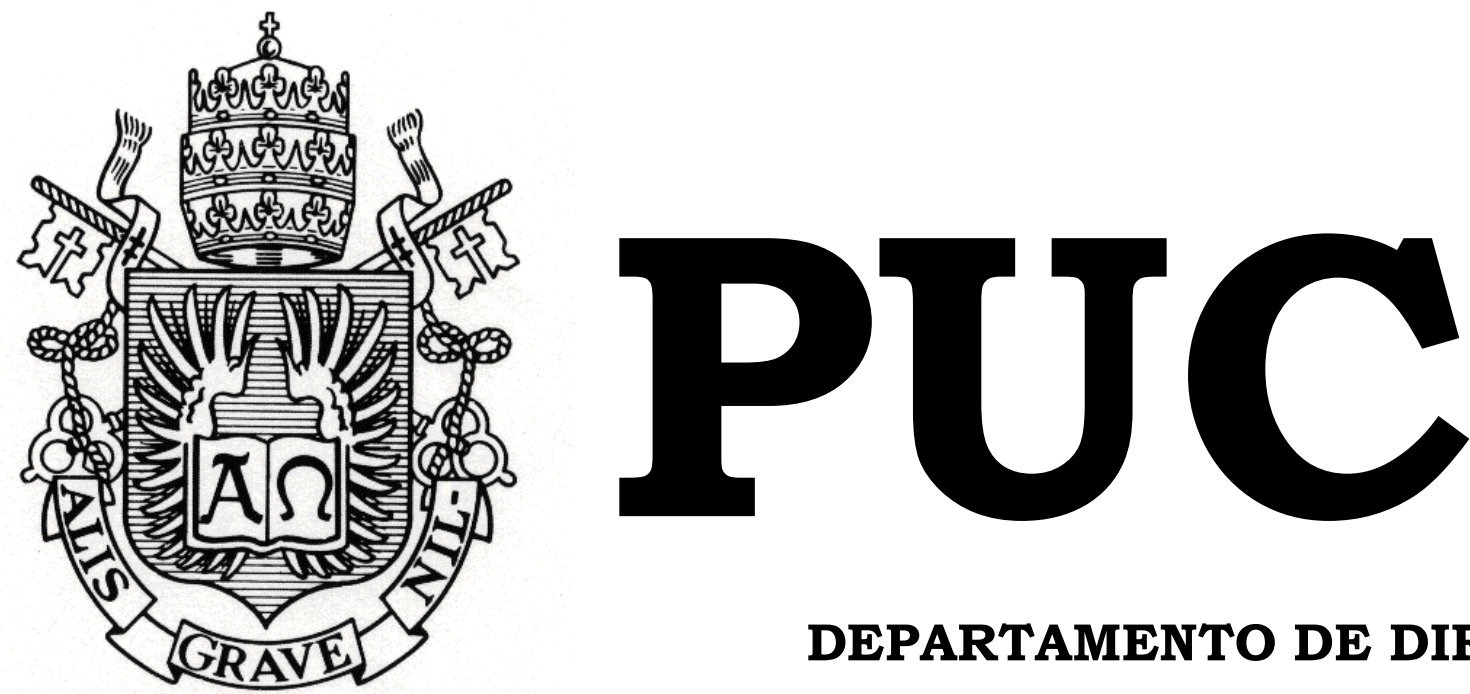

DEPARTAMENTO DE DIREITO

\title{
OS LIMITES DA MUTAÇÃO CONSTITUCIONAL À LUZ DA RECLAMAÇÃO No. 4335/AC
}

por

RICHANNE MOTA DE SOUZA

ORIENTADOR: Fábio Leite

2008.2

PONTIFÍCIA UNIVERSIDADE CATÓLICA DO RIO DE JANEIRO

RUA MARQUÊS DE SÃO VICENTE, 225 - CEP 22453-900

RIO DE JANEIRO - BRASIL 


\title{
OS LIMITES DA MUTAÇÃO CONSTITUCIONAL À LUZ DA RECLAMAÇÃO No. 4335/AC
}

\author{
por
}

\section{RICHANNE MOTA DE SOUZA}

\begin{abstract}
Monografia apresentada ao Departamento de Direito da Pontificia Universidade Católica do Rio de Janeiro (PUC-Rio) para a obtenção do Título de Bacharel em Direito.
\end{abstract}

Orientador(a): Fábio Leite 
Com muito amor, aos meus pais Ricardo José de Souza e Ana Lúcia Mota de Souza. 


\section{AGRADECIMENTOS}

- aos meus pais e meu irmão, por tudo que representam na minha vida e pela atenção que me dedicaram.

- aos meus familiares, pelo apoio emocional.

- ao Professor Fábio Leite, pela orientação, colaboração, disponibilidade e paciência.

- à Professora Flávia Bahia, pelos conselhos e material disponibilizado.

- à Professora Rachel Herdy, pelo auxílio na formatação do trabalho.

- aos funcionários da Biblioteca da PUC, da Biblioteca do TJRJ e da Biblioteca Nacional pelo auxílio na busca de materiais.

- aos amigos que a PUC me trouxe, em especial, André, Bianca, Camila, Fernanda, Júlia, Juliana, Leonora, Patrícia, Pedro, Pryscilla e Raquel, pela colaboração teórica e emocional. 


\section{RESUMO}

O trabalho tem por objetivo a análise dos limites à realização de mutações constitucionais com base no estudo da Reclamação 4335/AC. Pretende-se mostrar que a realização de mutações constitucionais é necessária, uma vez que a sociedade é dinâmica e os meios formais de reforma da Constituição não são suficientes para acompanhar todas as modificações da sociedade. Nesse cenário ganham força os processos informais de reforma da Constituição, permitindo uma maior coerência entre o texto constitucional e a realidade. A questão polêmica surge em delimitar até que ponto pode ser realizada uma mutação constitucional, sem qualquer alteração formal do texto constitucional. Até que ponto essa mudança informal seria legítima? Essa é a questão central da Reclamação 4335, uma vez que o Ministro Gilmar Mendes, acompanhado pelo Ministro Eros Grau, ambos do Supremo Tribunal Federal, defendem uma mudança radical no controle de constitucionalidade brasileiro, com o fundamento de se tratar de uma mutação constitucional. É de discutível legitimidade tal decisão uma vez que a Constituição Federal é clara quando trata do tema, e tal interpretação na verdade violaria não só o texto constitucional como também o princípio da separação dos poderes. Será possível modificação desse porte, que não são compatíveis com a letra da Constituição, serem realizadas por tais

mecanismos informais de reforma, sem que seja devidamente alterado o texto constitucional?

\section{Palavras Chaves}

Direito Constitucional - Mutação Constitucional - Processo Informal de Mudança da Constituição - Controle de Constitucionalidade - Jurisdição Constitucional - Usurpação de Poderes 


\section{SUMÁRIO}

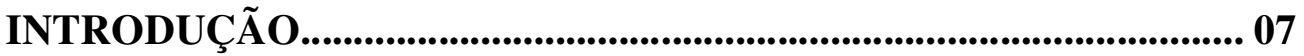

Capítulo 1: DA MUTAÇÃO CONSTITUCIONAL ................................. 10

1.1. Considerações Introdutórias.......................................................... 10

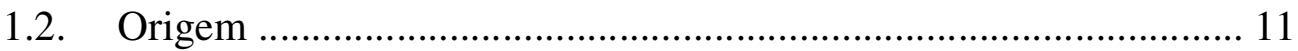

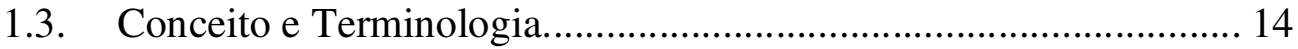

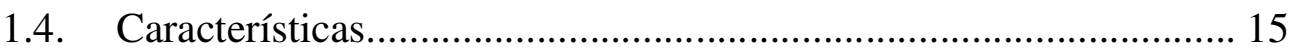

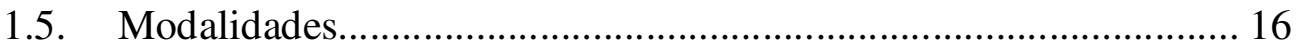

1.6. Interpretação Constitucional como forma de Mutação

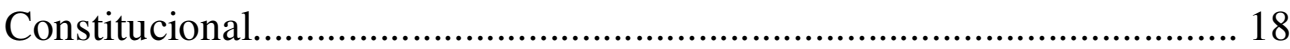

1.6.1. Métodos Clássicos de Interpretação......................................... 20

1.6.2. Os Princípios na Interpretação Constitucional....................... 23

1.6.3. Espécies de Interpretação....................................................... 25

1.6.4. Mutação por Interpretação Constitucional............................. 29

1.7. Costume Constitucional como forma de Mutação

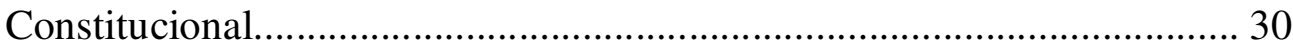

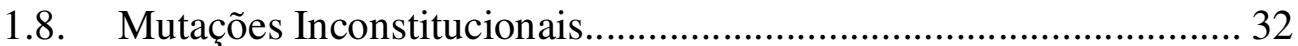

1.8.1. Mutações Manifestamente Inconstitucionais........................... 32

1.8.2. Processos Anômalos de Mutação........................................... 33

Capítulo 2: DO CONTROLE DE CONSTITUCIONALIDADE.......... 35

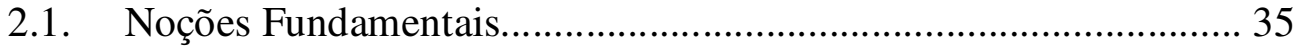

2.2. Sistema Brasileiro de Controle de Constitucionalidade................... 36

2.3. Controle Concentrado e Efeitos da Decisão..................................... 38

2.4. Controle Difuso e Efeitos da Decisão............................................... 42

2.5. Papel do Senado Federal no Controle Difuso.................................... 45 


\section{Capítulo 3: RECLAMAÇÃ̃ $\mathbf{N}^{\circ} .4335$ E A SUPOSTA MUTAÇÃO}

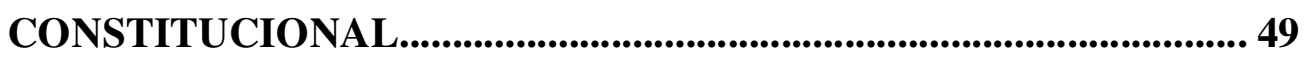

3.1. Jurisdição Constitucional e Limites da Interpretação

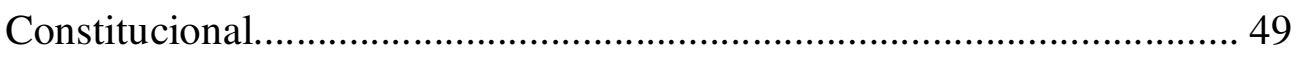

3.2. Análise da Reclamação $n^{\circ}$. 4335/AC.................................................. 52

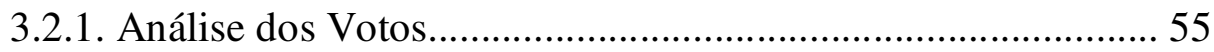

3.2.2. A Suposta Mutação (In)Constitucional...................................... 59

3.3. Abstrativização do Controle Difuso........................................................ 60

3.4. Mutação Inconstitucional e Princípio da Separação dos

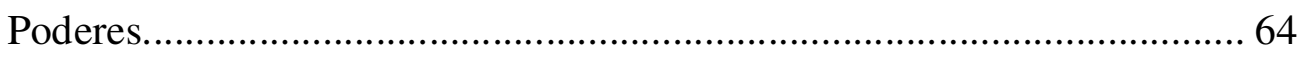

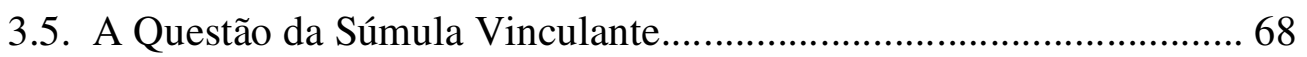

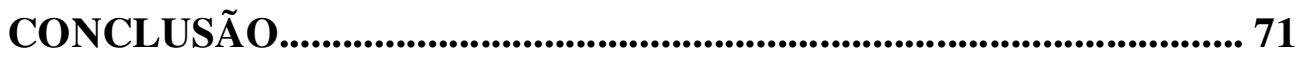

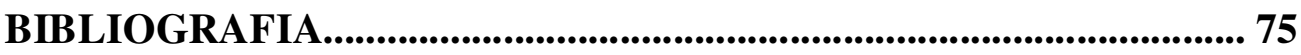




\section{INTRODUÇÃO}

Neste trabalho pretendo abordar o tema das mutações constitucionais, principalmente no tocante aos limites da sua utilização, tendo como referência a Reclamação ${ }^{\circ}$. 4335/AC, ainda em julgamento no Supremo Tribunal Federal.

No bojo da referida Reclamação, os Ministros Gilmar Mendes e Eros Grau proferiram seus votos no sentido de que as decisões de inconstitucionalidade do Supremo Tribunal Federal, ainda que em controle difuso, seriam dotadas de efeito vinculante. Defendem eles que, em razão de uma mutação constitucional, o papel do Senado Federal tornou-se meramente burocrático, apenas de formalizar a publicação da norma. Entretanto, essa proposta de mutação constitucional defendida pelos Ministros implicaria uma redefinição do sistema de controle de constitucionalidade vigente no país.

Diante desses votos polêmicos, ganha destaque o estudo das mutações constitucionais, sua origem, seu conceito, suas formas, sua aplicação e, principalmente, seus limites.

A sociedade é dinâmica e, para que a Constituição subsista, serão necessários mecanismos de adaptação às evoluções sociais. Muitas constituições já possuem dispositivos prevendo a possibilidade de reforma da constituição. Todavia, são mecanismos formais e burocráticos que não são suficientes para acompanhar todas as mudanças na sociedade. Em razão disso, o fenômeno da mutação constitucional adquiriu importância, pois permite que a Constituição possa se adaptar à realidade e às evoluções políticas, sociais e econômicas, através de mecanismos informais, sem a alteração do texto constitucional.

Os primeiros relatos de estudos sobre a mutação constitucional surgiram com teóricos alemães, à luz da Constituição Bismarckiana. O conceito de mutação constitucional não é uniforme na doutrina. Originariamente o conceito foi formulado pelo alemão Paul Laband, que, apesar de encarar a Constituição como uma norma jurídica em sentido 
formal, permite a sua modificação sem alteração redacional principalmente nas questões concernentes à essência do Estado.

Hsü Dau-Lin sistematizou o estudo da matéria e, a partir da incongruência entre normas constitucionais e a realidade constitucional, definiu o fenômeno da mutação constitucional como uma contraposição produzida em muitas constituições escritas, com a situação jurídica real. Para esse autor, existem quatro tipos de mutações constitucionais: mutação da constituição mediante uma prática estatal que não viola formalmente a constituição (realidade sem norma); mutação da Constituição mediante a impossibilidade de exercer certos direitos estatuídos constitucionalmente (norma sem realidade); mutação da Constituição mediante uma prática estatal contraditória a Constituição (norma com realidade); e a mutação da constituição mediante a sua interpretação (norma com realidade). ${ }^{1}$

Anna Cândida da Cunha Ferraz agrupa as modalidades de mutação constitucional mais freqüentemente abordadas na doutrina em interpretação constitucional, nas suas diversas formas (legislativa, judicial e administrativa) e usos e costumes constitucionais ${ }^{2}$.

Entretanto, existem limites à realização dessas mutações, sendo necessário o respeito aos princípios estruturais, políticos e jurídicos da Constituição, para que não ocorra a constitucionalização de atos em inequívoco contraste com a constituição escrita ${ }^{3}$. É característica fundamental da noção de mutação constitucional a alteração do sentido, alcance e significado de uma norma constitucional, sem que haja a violação da letra e do espírito da Constituição.

\footnotetext{
${ }^{1}$ DAU-LIN, Hsü. Mutación de la Constitución. Tradução FÖSTER, Christian. Onati: IVAP Instituto Vasco de Administración Pública Herri-Arduralarizaren Euskal Erakundea, 1998, p. 2931. Apud VECCHI, Cristiano Brandão. A mutação constitucional: uma abordagem Alemã. Rio de Janeiro, 2005. Dissertação de Mestrado - Departamento de Direito, Pontifícia Universidade Católica do Rio de Janeiro, pag. 105.

2 FERRAZ, Anna Cândida da Cunha. Processos Informais de Mudança da Constituição: Mutações Constitucionais e Mutações Inconstitucionais. São Paulo: 1986, pag. 13.
} 


\section{Plano de Trabalho}

Para sua melhor exposição, dividi o presente trabalho em três capítulos. No primeiro capítulo, dediquei-me à análise completa do fenômeno da mutação constitucional, apontando a origem, o conceito, a terminologia, as modalidades, incluindo a interpretação constitucional e os costumes constitucionais, e, também, os seus limites, para que não ocorra uma verdadeira mutação "inconstitucional".

No capítulo seguinte, para melhor esclarecer a questão constitucional envolvida na Reclamação $\mathrm{n}^{\circ}$. 4335/AC, procurei tratar, de forma sucinta, a questão do controle de constitucionalidade, abordando noções fundamentais, o sistema de controle de constitucionalidade no Brasil, com destaque para o controle concentrado/abstrato e seus efeitos, o controle difuso/concreto e seus efeitos e o papel do Senado Federal no controle difuso.

No terceiro capítulo, procurei estabelecer a conexão das questões abordadas na Reclamação $n^{\circ}$. 4335/AC, expondo a questão da jurisdição constitucional e dos limites da interpretação constitucional. Para o perfeito entendimento da polêmica acerca da proposta de mutação constitucional na Reclamação ${ }^{\circ}$. 4335/AC, apresentei os votos de forma detalhada. Fizeramse necessárias, também, algumas observações sobre a abstrativização do controle difuso, o princípio da separação dos poderes e a questão da súmula vinculante.

\footnotetext{
${ }^{3}$ CANOTILHO, José Joaquim. Direito Constitucional e Teoria da Constituição. $2^{\mathrm{a}}$ edição. Coimbra: Almedina, 1998. Apud VECCHI, Cristiano Brandão, op. cit., pag. 134.
} 


\section{CAPÍTULO 1}

\section{DA MUTAÇÃO CONSTITUCIONAL}

\subsection{Considerações Introdutórias}

A realidade constitucional é dinâmica e, para que a Constituição subsista, ela deverá conter mecanismos que propiciem sua constante adaptação às transformações sociais, políticas e econômicas da sociedade. A noção de Constituição eterna, definitiva e imodificável presente no Código de Hamurabi ${ }^{4}$ está ultrapassada. Atualmente, diante dessa realidade social cambiante e em constante processo de evolução, seria ingênuo considerar inalterável a Constituição. Nesse cenário, Bulos intitula as constituições de “organismos vivos, em íntimo vínculo dialético com o meio circundante, com as forças presentes na sociedade". 5

Destaca-se que a Constituição, como lei fundamental de um Estado, é dotada de estabilidade, o que não significa que seja imutável. A estabilidade é o elemento estático da Constituição, conferindo certo equilíbrio ao texto constitucional e, conseqüentemente, ao próprio Estado. Mas a Constituição também deve conter instrumentos que possibilitem seu constante enquadramento com as evoluções sociais, isto é, o seu elemento dinâmico.

Essa mutabilidade é necessária para a eficácia constitucional, e, em virtude disso, muitos textos constitucionais já consagram mecanismos de reforma da Constituição, indicando a forma, os requisitos e os limites dessas alterações. A nossa Carta Maior é obra do poder constituinte originário, que, após a sua elaboração, se exauriu. Porém, ciente da necessidade de a Constituição se adaptar a posteriores modificações na sociedade, esse poder constituinte originário já definiu a competência, o

\footnotetext{
4 “Nos dias que hão de vir, e para todo o sempre, o governante que estiver no País observará as palavras de justiça que estão escritas no meu obelisco. Ele não alterará o direito do Estado, por mim formulado, ou as leis, por mim promulgadas, nem danificará as minhas esculturas". Apud. BULOS, Uadi Lammêgo. Mutação Constitucional. São Paulo: Saraiva, 1997, p. 1-2.

${ }^{5}$ BULOS, Uadi Lammêgo, op.cit., p. 3.
} 
modo de realização e os limites do poder reformador. Assim, de acordo com o artigo 60 da Constituição, ela somente poderá ser alterada por proposta do presidente da República ou de um terço, no mínimo, dos membros da Câmara dos Deputados ou do Senado Federal, ou ainda, de mais da metade das Assembléias Legislativas das unidades da Federação, manifestando-se, cada uma delas, pela maioria relativa de seus membros. Essa proposta somente se tornará Emenda Constitucional se for aprovada por três quintos dos membros, em dois turnos de votação em cada casa.

Note-se que esse poder reformador, além dessas limitações formais ${ }^{6}$, ainda sofre limitações circunstanciais, não sendo permitindo a alteração da Constituição durante os estados de exceção, incluindo a intervenção federal, e limitações materiais, não podendo ser objeto de emenda a forma federativa de Estado, o voto direto, secreto, universal e periódico, a separação dos poderes e os direitos e garantias individuais, além de outras limitações materiais implícitas apontadas pela doutrina.

Entretanto, esse procedimento burocrático de reforma (muitas vezes) não é suficiente para acompanhar as inúmeras transformações sociais. Nesse contexto, ganham destaque as mutações constitucionais, a saber, mecanismos informais de mudança da Constituição, que modificam o significado, sentido e alcance de disposições constitucionais, sem alteração do seu texto.

\subsection{Origem}

Os primeiros estudos sobre o tema surgiram na Alemanha, sob a égide da Constituição de 1871, que sofria constantes mudanças a respeito do funcionamento das instituições do Reich, sem que fossem realizadas reformas no texto constitucional. Os teóricos da Escola Alemã de Direito

\footnotetext{
${ }^{6}$ De acordo com o professor Fábio Carvalho Leite o procedimento para aprovação de emendas constitucionais não deve ser considerado como limite procedimental, idéia que somente poderia ser aceita com base em análise comparativa com o procedimento para elaboração dos demais atos normativos. Assim, defende o professor que "as limitações devem ser consideradas por si só, e não em comparação com o processo legislativo ordinário”. In: LEITE, Fábio Carvalho. Revisão da
} 
Público consideravam as mutações constitucionais um problema, pois que as mudanças na constituição ocorriam sem a observância de um processo formal de alteração. Depois da primeira Grande Guerra, essa visão formalista/positivista ficou abalada na Alemanha e a mutação constitucional passou a ser entendida como elemento inerente à própria noção de Constituição.

O conceito de mutação constitucional foi originariamente formulado por Paul Laband. Apesar da visão normativista de Constituição, o mencionado autor reconhecia a possibilidade de a ação do Estado modificála sem que fosse necessária a alteração formal do texto, especialmente no que se referia à essência do Estado. A partir da análise dos casos mais importantes da época, Laband observou três caminhos distintos de mutações constitucionais: 1) por meio de leis que regulavam elementos centrais do Estado, não previstos ou previstos de maneira colateral pela Constituição; 2) por meio de leis que modificavam elementos centrais do Estado em contradição com o texto da Constituição; 3) e pelos usos e costumes dos poderes públicos que modificavam elementos centrais do Estado.

Inspirado nos estudos de Laband, Georg Jellink diferenciou o processo formal de alteração da Constituição do processo informal, com base no critério da intencionalidade. Desse modo, enquanto a reforma era oriunda de um ato de vontade em modificar a Constituição, a mutação constitucional caracterizava-se pela falta de consciência do efeito da mudança. Jellinek apontava os atos normativos, a interpretação, a prática parlamentar, administrativa e jurisdicional, a necessidade política, o desuso, as lacunas e integração, os usos e costumes, como vias para a realização de mutações constitucionais. ${ }^{8}$

doutrina dos limites ao poder de reforma na constituição de 1988 (reflexões a partir do estudo de dois casos), p. 107.

${ }^{7}$ VECCHI, Cristiano Brandão, Op. cit., p. 56.

${ }^{8}$ VECCHI, Cristiano Brandão. Op.cit., p. 57-8. 
Um dos estudos mais completos sobre mutação constitucional foi confeccionado pelo jurista, de formação oriental, Hsü Dau-Lin, em 1932. ${ }^{9}$ Ele aponta o fenômeno da modificação informal da Constituição como resultado da incongruência entre as normas constitucionais e a realidade constitucional. Dau-Lin aponta quatro tipos de mutações constitucionais: 1) mutação da Constituição mediante uma prática estatal que não viola formalmente a Constituição (realidade sem norma); 2) mutação da Constituição mediante a impossibilidade de exercer certos direitos estatuídos constitucionalmente (norma sem realidade); 3) mutação da Constituição mediante uma prática estatal contraditória à Constituição (norma com realidade); 4) e mutação da Constituição mediante a sua interpretação (norma com realidade). ${ }^{10}$

Diversas teorias surgiram para explicar o fenômeno das mutações constitucionais. Dentre as de maior relevo, encontravam-se a teoria do direito consuetudinário e a que interpreta a mutação como violação à Constituição. Dau-Lin rejeita essas teorias, apontando que a justificativa para a ocorrência dessas transformações informais reside na própria natureza da Constituição como instrumento regulador da vida estatal, o que pressupõe constantes transformações.

Para Dau-Lin, existem duas espécies de mutações constitucionais. Em sentido formal, a mutação resultaria na alteração do texto da lei, quando a situação constitucional real já não se mostrar compatível com o direito constitucional positivo. Já a mutação constitucional em sentido material se revela quando as relações jurídicas na realidade da vida estatal se desenvolvem em contradição com o sistema. ${ }^{11}$

De acordo com o autor, as duas espécies de mutação citadas ocorrem pelos mesmos motivos: a peculiaridade valorativa do direito constitucional, a imperfeição das normas constitucionais em face das reais necessidades da

\footnotetext{
${ }^{9}$ DAU-LIN, Hsü. Mutación de la Constitución. Tradução FÖSTER, Christian. Onati: IVAP Instituto Vasco de Administración Pública Herri-Arduralarizaren Euskal Erakundea, 1998. Apud VECCHI, Cristiano Brandão, op. cit., pag 79.

${ }^{10}$ DAU-LIN, Hsü. Op. cit, p. 29-31. Apud VECCHI, Cristiano Brandão, op. cit., pag 81.
} 
vida estatal, sua regulação elástica, a natureza teleológica do Estado, a autogarantia da Constituição e a impossibilidade de fiscalizar os órgãos supremos do Estado. ${ }^{12}$

\subsection{Conceito e Terminologia}

O fenômeno da mutação constitucional se refere a alterações no significado, sentido ou alcance de dispositivos constitucionais, sem que seja realizado o mecanismo formal previsto para a reforma da Constituição. Como observa Uadi Bulos:

Assim, denomina-se mutação constitucional o processo informal de mudança da Constituição, por meio do qual são atribuídos novos sentidos, conteúdos até então não ressaltados à letra da Lex Legum, quer através da interpretação em suas diversas modalidades e métodos, quer por intermédio da construção (construction), bem como dos usos e costumes constitucionais. ${ }^{13}$

Na doutrina, não é uniforme a terminologia utilizada para cognominar as mudanças informais das constituições. O termo mais comum é "mutação constitucional", que tem origem na expressão "Verfassungswandlung" criada por Laband. ${ }^{14}$ Jorge Miranda, em seu Manual de Direito Constitucional, refere-se ao mencionado fenômeno como "vicissitude constitucional tácita”. Já Gomes Canotilho utiliza a expressão "transições constitucionais". Ao tratar da interpretação sistemática da Constituição, Pietro Merola Chierchia adota a terminologia "processos de fato". Luiz Pinto Ferreira, denomina de "mudança material" as alterações constitucionais provenientes de interpretação e costumes constitucionais. "Processos informais, não formais ou indiretos" é a terminologia utilizada por Anna Cândida da Cunha Ferraz em sua obra. ${ }^{15}$

Essas inúmeras denominações resultam do fato de serem as mutações constitucionais mudanças difusas, não organizadas e espontâneas. De

\footnotetext{
${ }^{11}$ VECCHI, Cristiano Brandão, op. cit., pag 101-2.

${ }^{12}$ VECCHI, Cristiano Brandão, op. cit., pag 102.

${ }^{13}$ BULOS, Uadi Lammêgo, op.cit, p. 57.

${ }^{14}$ VECCHI, Cristiano Brandão, op. cit., pag 104.

${ }^{15}$ Levantamento realizado por BULOS, Uadi Lammêgo, op.cit, p. 57-8.
} 
qualquer forma, seja qual for a terminologia adotada, referem-se a mudanças da Constituição operadas fora do exercício do poder reformador instituído.

Anna Cândida da Cunha Ferraz observa que na prática a noção de mutações constitucionais, por vezes, inclui dois tipos de alterações informais: as que não violam a Constituição e as que contrariam a Constituição. De acordo com a autora:

\begin{abstract}
A expressão mutação constitucional é reservada somente para todo e qualquer processo que altere ou modifique o sentido, o significado e o alcance da Constituição sem contrariá-la; as modalidades de processos que introduzem alteração constitucional, contrariando a Constituição, ultrapassando os limites constitucionais fixados pelas normas; enfim, as alterações inconstitucionais são designadas mutações inconstitucionais. ${ }^{16}$
\end{abstract}

\title{
1.4. Características
}

As alterações na realidade constitucional, provocadas pelas mutações constitucionais, realizam-se de forma lenta, sem qualquer modificação no texto da Carta Maior.

Bulos apresenta três características inerentes aos processos informais de mudança da Constituição. A primeira delas é o fato de a mutação ser constitucional, devendo observar as demais disposições presentes na Constituição. A segunda se refere à natureza fática desse processo, de modo que as mudanças informais ocorrem naturalmente, de forma espontânea e sem qualquer previsibilidade a respeito do momento em que serão vislumbradas. E, por fim, essas transformações ocorrem em momentos distintos, espaçados, perante situações diferentes. ${ }^{17}$ Konrad Hesse critica essa última característica, afirmando não ser necessário um período largo de tempo para que as mutações constitucionais se concretizem.

Anna Cândida da Cunha Ferraz aponta duas características como fundamentais na compreensão desses processos não formais de alteração da Constituição. Primeiramente, como já sinalizado, afirma que o caráter

\footnotetext{
${ }^{16}$ FERRAZ, Anna Cândida da Cunha. Op. cit., p. 10.

${ }^{17}$ BULOS, Uadi Lammêgo, op.cit, p. 61.
} 
marcante das mutações constitucionais reside no fato de serem alterações de sentido, significado e alcance do texto constitucional, sem que a sua letra ou espírito sejam violados. A segunda característica apontada pela autora indica uma alteração da Constituição realizada fora das modalidades organizadas de exercício do poder constituinte instituído. Essas alterações informais são manifestações de uma espécie não organizada de poder constituinte, que recebeu, por Georges Burdeau, a denominação de poder constituinte difuso. ${ }^{18}$ Esse poder é implícito e limitado, restringindo-se a precisar ou modificar o sentido, o significado e o alcance dos dispositivos constitucionais, sem que lhe seja permitido à violação do texto constitucional. Segundo Anna Cândida da Cunha Ferraz:

\begin{abstract}
Em resumo, a mutação constitucional, para que mereça o qualificativo, deve satisfazer, portanto, os requisitos apontados. Em primeiro lugar, importa sempre em alteração do sentido, do significado ou do alcance da norma constitucional. Em segundo lugar, essa mutação não ofende a letra nem o espírito da Constituição: é pois, constitucional. Finalmente, a alteração da Constituição se processa por modo ou meio diferentes das formas organizadas de poder constituinte instituído ou derivado. ${ }^{19}$
\end{abstract}

\title{
1.5. Modalidades
}

As modalidades de mutações constitucionais não são tratadas de maneira uniforme pela doutrina. Os critérios utilizados pelos autores são os mais variados possíveis. Uadi Bulos, em sua obra sobre mutação constitucional, realizou um levantamento, que será apresentado nesse tópico, com as modalidades apontadas por teóricos de renome no assunto. ${ }^{20}$

Hsü Dau-Lin, Pablo Lucas Verdú e Manuel Garcia Pelayo apontam quatro categorias de mutações constitucionais: 1) mutação constitucional por meio de prática que não viola a Constituição; 2) mutação constitucional por impossibilidade do exercício de determinada atribuição constitucional;

\footnotetext{
${ }^{18}$ BURDEAU, Georges. Traité de Science Politique. Apud FERRAZ, Anna Cândida da Cunha, op.cit., p. 10.

${ }^{19}$ FERRAZ, Anna Cândida da Cunha, op.cit, p. 11.

${ }^{20}$ BULOS, Uadi Lammêgo, op.cit, p. 63-70.
} 
3) mutação constitucional em decorrência de prática que viola preceitos da Carta Maior; 4) e mutação constitucional através da interpretação.

Paulo Biscaretti Di Ruffia adota essa classificação, incluindo mais dois critérios: 5) modificações por atos estatais de caráter normativo ou jurisdicional; 6) e mudanças por fatos de caráter jurídico, de natureza político-social ou simplesmente práticas constitucionais.

Georg Jellinek também agrupa as mutações constitucionais em quatro categorias: 1) mutação constitucional por atividade legislativa; 2) mutação constitucional por práticas judiciais; 3) mutações constitucionais por práticas administrativo-governamentais; 4) e mutações constitucionais pelo desuso das faculdades estatais.

Milton Campos apresenta as mutações constitucionais por complementação legislativa, por construção judiciária e por consenso costumeiro.

José Horácio Meirelles Teixeira aponta três modalidades de processos informais de alteração da Constituição: 1) por meio de interpretação constitucional; 2) pelos costumes constitucionais; 3) e pela complementação legislativa à Constituição.

Bulos propõe uma classificação quadripartide: 1) mutações constitucionais operadas pela interpretação constitucional, nas suas diferentes modalidades e métodos; 2) mutação constitucional decorrente de práticas constitucionais; 3) mutações constitucionais pela construção constitucional; 4) e mutações inconstitucionais.

E, por fim, Anna Cândida da Cunha Ferraz agrupa as modalidades mais freqüentemente apontadas pela doutrina em interpretação constitucional, nas suas diversas modalidades, e em usos e costumes constitucionais. Todavia, complementa, observando que, na prática, várias modificações ofendem a Constituição, o que ela denomina de mutações inconstitucionais. $^{21}$

\footnotetext{
${ }^{21}$ FERRAZ, Anna Cândida da Cunha, op.cit, p. 13.
} 


\title{
1.6. Interpretação Constitucional como forma de Mutação Constitucional
}

A interpretação constitucional é uma forma tradicional e comum para a realização de mutações constitucionais. "Interpretar a Constituição é conhecê-la, não apenas em sua letra, mas também, em seu espírito, em seus significados mais profundos e em seu verdadeiro alcance". ${ }^{22}$ Esse trabalho interpretativo poderá gerar uma mutação constitucional quando ocorrer a alteração do sentido, alcance ou significado da norma constitucional, sem que haja uma modificação formal de seu texto.

A interpretação é "a atividade prática de revelar o conteúdo, o significado e o alcance de uma norma, tendo por finalidade fazê-la incidir em um caso concreto". ${ }^{23}$ Essa atividade interpretativa refere-se à exploração do próprio texto constitucional, para extração do seu verdadeiro significado. Diferentemente, nas hipóteses de lacunas constitucionais opera-se a construção que, ao contrário da interpretação, ultrapassa os limites do texto constitucional, recebendo influência de considerações extrínsecas.

A doutrina diverge quanto ao enquadramento da interpretação constitucional. Alguns autores acreditam não haver diferença entre a interpretação jurídica em geral e a interpretação constitucional, já que o processo que permite a definição do alcance, sentido e significado das normas é o mesmo.

\begin{abstract}
Nesse ponto, convém lembrar a única nuaça - mas não-especificidade - da interpretação da Constituição: a da natureza subconstitucional dos preceitos ordinários que, para serem recepcionados, com ela devem compatibilizar-se [...] inexiste uma interpretação constitucional com foros de especificidade. O que há é uma interpretação jurídica das normas constitucionais. Os mesmos critérios que presidem à hermenêutica em geral servem para desvendar o sentido, o significado e o alcance das normas constitucionais. ${ }^{24}$
\end{abstract}

Já Anna Cândida da Cunha Ferraz, acompanhada pela maioria da doutrina, defende que a interpretação constitucional é uma espécie de interpretação

\footnotetext{
${ }^{22}$ FERRAZ, Anna Cândida da Cunha, op. cit, p. 22.

${ }^{23}$ BARROSO, Luís Roberto. Interpretação e Aplicação da Constituição. $6^{\mathrm{a}}$ ed., rev., atual. e ampl. - São Paulo: Saraiva, 2004, p. 103.

${ }^{24}$ BULOS, Uadi Lammêgo. Op. cit., p. 100-6.
} 
jurídica com algumas peculiaridades que derivam de atributos inerentes à matéria constitucional, principalmente, no tocante ao elemento político e à tipologia das normas constitucionais.

A natureza política intrínseca à norma constitucional faz com que a sua interpretação não esteja limitada ao sentido, alcance e significado do texto, havendo forte influência dos valores políticos. Assim, quando a norma constitucional é interpretada de acordo com o elemento político a ela inerente, poderá surgir um novo conteúdo, fato este que favorece a realização de mutações constitucionais.

Segundo o constitucionalista Carmelo Carbone, o fator político influi na interpretação constitucional para definir o conteúdo dos princípios constitucionais que realizam o conteúdo dos princípios políticos correspondentes, para determinar a atualidade do regime político à base do qual é analisada a norma na interpretação, e para concretizar o fim público, que dá a medida da discricionariedade atribuída pelas normas

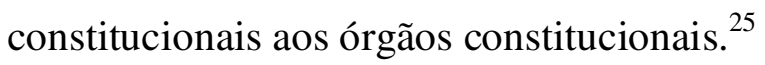

A tipologia das normas constitucionais é outro elemento para especificar a interpretação constitucional. De acordo com José Afonso da Silva, as normas constitucionais podem ser classificadas em: a) normas constitucionais de eficácia plena e aplicabilidade direta, aquelas que incidem imediatamente às situações concretas, sem que seja necessária a elaboração de legislação complementar; b) normas constitucionais de eficácia contida e aplicabilidade direta, aquelas que também possuem aplicabilidade imediata, mas estão sujeitas a restrições futuras por parte do legislador infraconstitucional; c) e as normas constitucionais de eficácia limitada ou reduzida, aquelas não auto-aplicáveis, pois que, dependem de uma complementação legislativa para sua concretização. Essa última classificação se subdivide em normas institutivas ou organizatórias e normas programáticas. O primeiro grupo se refere às instituições, pessoas e

\footnotetext{
${ }^{25}$ CARBONE, Carmelo. L'interpretazione delle Norme Constituzionale. Padova: CEDAM, 1951, p. 29-30. Apud FERRAZ, Anna Cândida da Cunha, op. cit, p. 26.
} 
órgãos criados pela Constituição, mas que dependem de regulamentação futura por parte do poder público. Já as normas programáticas, normalmente relacionadas com as políticas públicas, são aquelas que criam programas e diretrizes que devem ser cumpridas pelo Estado. ${ }^{26}$

Essa tipologia das normas constitucionais influi na atuação do intérprete constitucional, tanto na escolha dos meios de interpretação, quanto nos limites que as diferentes categorias de normas impõem ao agente e no grau de discricionariedade da interpretação. Dessa forma, as normas constitucionais e seus diferentes tipos devem ser considerados na interpretação constitucional como processo de mutação constitucional.

Luís Roberto Barroso, no mesmo sentido, defende que "a interpretação constitucional serve-se de alguns princípios próprios e apresenta especificidades e complexidades que lhe são inerentes. Mas isso não a retira do âmbito da interpretação geral do direito". ${ }^{27} \mathrm{E}$ ainda aponta quatro peculiaridades das normas constitucionais que influenciam a interpretação constitucional, a saber: a) a superioridade hierárquica, em razão da supremacia da Constituição no ordenamento jurídico, funcionando como o fundamento de validade das demais normas; b) a natureza da linguagem constitucional, decorrente do fato da Constituição possuir normas de conteúdo aberto que conferem uma maior discricionariedade ao intérprete; c) o conteúdo específico das normas constitucionais, incluindo normas de conduta, de organização e programáticas, diferentemente do conteúdo das demais normas legais; d) e o caráter político, intrínseco às normas constitucionais. ${ }^{28}$

\subsubsection{Métodos Clássicos de Interpretação}

Neste tema possui destaque o trabalho de Friedrich Carl Von Savigny, que primeiro distinguiu os métodos em gramatical, sistemático e histórico. A

\footnotetext{
${ }^{26}$ SILVA, José Afonso da. Aplicabilidade das Normas Constitucionais. $2^{\mathrm{a}}$ ed. São Paulo: Revista dos Tribunais, 1982. Apud BULOS, Uadi Lammêgo. Op. cit, p. 97-8.

${ }^{27}$ BARROSO, Luís Roberto. Op. cit.,p. 104.

${ }^{28}$ BARROSO, Luís Roberto. Op. cit.,p. 107-12.
} 
doutrina não é uniforme na enumeração dos métodos. Além dos originariamente percebidos por Savigny, são comumente apontados os métodos teleológico, lógico e evolutivo.

Luís Roberto Barroso destaca que nenhum desses métodos pode ser encarado de forma absoluta, devendo ser aplicados de forma combinada. "A interpretação se faz a partir do texto da norma (interpretação gramatical), de sua conexão (interpretação sistemática), de sua finalidade (interpretação teleológica) e de seu processo de criação (interpretação histórica)" ${ }^{29}$

Quando todos os métodos indicam o mesmo resultado, este será a solução oriunda da convergência dos métodos. A problemática se dá quando os diferentes métodos conduzem a diferentes resultados, uma vez que não há hierarquia entre os métodos e, tampouco, existe um critério de desempate. Barroso aponta algumas diretrizes para a solução da questão. Assim, o método gramatical nunca deve ser descartado, uma vez que a interpretação não pode exceder os limites do texto constitucional. Em segundo lugar, o autor privilegia os métodos objetivos (sistemático e teleológico), deixando como última opção o método subjetivo (histórico). ${ }^{30}$

A interpretação gramatical ou literal busca o sentido, alcance e significado do texto constitucional a partir de princípios lingüísticos, observando o significado literal de cada palavra, a sua colocação na frase, a etimologia e a pontuação. Ela é o ponto de partida da interpretação constitucional, mas, na maioria das vezes, não é suficiente para a solução dos casos, necessitando da aplicação conjunta de outros métodos. Quando o intérprete, diante de termo suscetível de mais de uma interpretação, passa a interpretá-lo com o segundo sentido, não comumente utilizado, estará realizando uma mutação constitucional por interpretação gramatical.

A interpretação histórica tem como base os antecedentes da norma, desde os trabalhos de feitura do projeto de lei, a justificação, a exposição

\footnotetext{
${ }^{29}$ BARROSO, Luís Roberto. Op. cit, p. 125.

${ }^{30}$ BARROSO, Luís Roberto. Op. cit, p. 126.
} 
dos motivos, discussões, emendas e as condições culturais e psicológicas que resultaram na elaboração da lei, com o intuito de revelar a vontade do legislador no momento da criação da norma. Esse método não pode ser utilizado de tal forma que se torne um obstáculo à evolução interpretativa. Pode conduzir a realização de mutações constitucionais.

A interpretação sistemática tem como referência todo o sistema constitucional, promovendo o inter-relacionamento dos seus dispositivos. A norma constitucional, vista de forma isolada, pode não fazer muito sentido ou mesmo estar em contradição com outra norma. Em razão disso, é necessário enxergar o ordenamento jurídico como um único sistema, o que favorece a ocorrência de mutações constitucionais.

A interpretação teleológica tem por objetivo descobrir a finalidade da norma constitucional, tendo em vista os valores que ela pretende atingir. Nesse sentido, o artigo $5^{\circ}$, da Lei de Introdução ao Código Civil, possibilita que o intérprete adeque a norma constitucional às novas exigências sociais, sendo também, meio eficaz para a realização de mutações constitucionais.

A interpretação lógica pretende chegar ao conhecimento do direito mediante deduções lógicas ou silogismos. Todavia, acaba gerando uma jurisprudência mecânica que é prejudicial à sociedade.

A interpretação evolutiva ocorre quando, sem contrariar o texto constitucional, o intérprete cria novos conteúdos para as normas constitucionais, em razão de mudanças históricas ou de fatores políticos e sociais que não estavam presentes na mente do constituinte à época da elaboração da Constituição. A ocorrência de mutações constitucionais, por meio dessa interpretação, permite que as disposições constitucionais acompanhem a evolução dos valores sociais e dos fins inspiradores da Carta Maior, sem a observação do burocrático processo de reforma da Constituição.

Todos esses métodos clássicos possuem reconhecida importância no processo de interpretação. Todavia, atualmente a interpretação constitucional é, em grande parte, principiológica. Destaca-se que os 
métodos clássicos não foram substituídos, vez que continuam a ser utilizados no processo de interpretação.

\subsubsection{Os Princípios na Interpretação Constitucional}

A Teoria Pura do Direito, visualizada pelos positivistas, pretendeu tirar da norma toda espécie valorativa para sustentar a supremacia formal da Constituição. Essa concepção entrou em crise após a segunda Grande Guerra, ganhando força a doutrina pós-positivista, que sustentava a necessidade de abertura do sistema, com a inserção de carga valorativa ao texto constitucional e à atividade do intérprete.

Em verdade, os princípios são o oxigênio das Constituições na época do póspositivismo. [...] A importância vital que os princípios assumem para os ordenamentos jurídicos se torna cada vez mais evidente, sobretudo se lhes examinarmos a função e presença no corpo das Constituições contemporâneas, onde aparecem como pontos axiológicos de mais alto destaque e prestígio com que fundamentar na Hermenêutica dos tribunais a legitimidade dos preceitos da ordem constitucional. ${ }^{31}$

Nessa perspectiva moderna, a Constituição é composta de regras e princípios. As regras são normas concretas, mais objetivas e com pequena dose de subjetividade e os princípios são normas com forte conteúdo de justiça, ética e moral, e com maior grau de subjetividade.

Segundo Luís Roberto Barroso "a atividade interpretativa da Constituição deve começar pela identificação do princípio maior que rege o tema a ser apreciado, descendo do mais genérico ao mais específico, até chegar à formulação da regra concreta que vai reger a espécie". ${ }^{32}$ Nessa nova interpretação, os princípios a seguir merecem destaque.

O princípio da supremacia da Constituição estabelece que todo e qualquer ato jurídico, para subsistir, deve ser compatível com as normas constitucionais. A Constituição, obra do poder constituinte, é o fundamento de validade de todas as demais normas do ordenamento jurídico. Dessa

\footnotetext{
31 BONAVIDES, Paulo. Curso de Direito Constitucional. 14 ${ }^{\mathrm{a}}$. ed. rev. e atual. - São Paulo: Malheiros, 2004, p. 288-9.

${ }^{32}$ BARROSO, Luís Roberto. Op. cit., p. 151.
} 
forma, as normas anteriores à Constituição que lhe sejam contrárias não serão recepcionadas, as normas posteriores à Constituição que não sejam com ela compatíveis serão declaradas inconstitucionais e, consequientemente, retiradas do ordenamento jurídico, e, por fim, os atos internacionais, para que produzam efeitos dentro do país, também terão que observar os dispositivos constitucionais.

O princípio da presunção de constitucionalidade das leis e dos atos do Poder Público é decorrência do princípio da separação dos poderes. Desempenha importante papel na manutenção da imperatividade dos atos do poder público. Destaca-se que a presunção é relativa, podendo ser elidida por meio do controle da constitucionalidade das leis. Todavia, o Poder Judiciário somente poderá declarar a inconstitucionalidade da lei ou ato normativo quando for manifesta e inequívoca, e ainda, por um quorum de maioria absoluta. Na dúvida, prevalece a constitucionalidade, em nome dessa presunção.

O princípio da interpretação conforme a Constituição incide quando a norma legal comporta mais de uma interpretação e a escolha recai pela interpretação que não é a mais evidente, excluindo as demais, sem que haja alteração do texto. Não se trata apenas de um processo de interpretação, mas, também, de um meio de controle de constitucionalidade.

Pelo princípio da unidade da Constituição as normas constitucionais não devem ser analisadas como preceitos isolados, e sim como normas integradas em um sistema unitário de regras e princípios. Nos chamados "casos difíceis", aqueles que apresentam um conflito aparente entre normas constitucionais, será realizada uma ponderação de princípios com o intuito de apontar qual irá prevalecer naquele caso específico, mantendo a unidade da Constituição.

O princípio da razoabilidade nasce do princípio do devido processo legal substantivo no sistema norte americano. Esse princípio guarda afinidade com a idéia de equilíbrio, moderação e harmonia, buscando a solução que melhor atenda ao senso comum e aos valores vigentes em um 
dado momento. Possui um forte conteúdo subjetivo e abstrato, visando atingir a justiça no caso concreto.

O princípio da proporcionalidade foi desenvolvido pelo Tribunal Federal Alemão. É composto por três subprincípios, a saber, a adequação, a necessidade e a proporcionalidade em sentido estrito. Adequada seria a medida capaz de fomentar determinado fim. Necessária é aquela que, quando comparada a outras, restringiria, em menor escala, o direito fundamental violado. A proporcionalidade em sentido estrito seria o próprio juízo acerca da justiça da decisão.

De acordo com o princípio da máxima efetividade das normas constitucionais, o intérprete deverá extrair efeitos jurídicos de toda e qualquer norma da Constituição, inclusive daquelas que são, classicamente, taxadas de normas programáticas. Como decorrência desse princípio, será vedada toda interpretação que suprima ou diminua a finalidade da norma constitucional.

O princípio da correção funcional aponta para o respeito à forma como o constituinte originário estabeleceu as atribuições dos órgãos estatais. Assim, se a Constituição regula as funções estatais, é defeso ao intérprete exceder a essas prescrições. O princípio tem por objetivo preservar o pacto federativo e a separação dos poderes.

\begin{abstract}
A generalidade, abstração e capacidade de expansão dos princípios permite ao intérprete, muitas vezes, superar o legalismo estrito e buscar no próprio sistema a solução mais justa, superadora do summum jus, summa injuria. Mas são esses mesmos princípios que funcionam como limites interpretativos máximos, neutralizando o subjetivismo voluntarista dos sentimentos pessoais e das conveniências políticas, reduzindo a discricionariedade do aplicador da norma e impondo-lhe o dever de motivar o seu convencimento. ${ }^{33}$
\end{abstract}

\title{
1.6.3. Espécies de Interpretação
}

Quanto à sua origem, a interpretação constitucional pode ser orgânica ou não-orgânica. A interpretação constitucional orgânica é aquela realizada por órgãos dos três poderes estatais, que retiram da própria Constituição força

\footnotetext{
${ }^{33}$ BARROSO, Luís Roberto. Op. cit., p. 160.
} 
para aplicá-la. Por outro lado, a interpretação constitucional não-orgânica não é exercida por órgãos que tem por finalidade aplicar a Constituição, é aquela normalmente realizada pela ciência jurídica e pelos juristas. ${ }^{34}$

A interpretação constitucional orgânica pode ser legislativa, judicial ou administrativa.

A interpretação constitucional legislativa é "a atividade desenvolvida pelo órgão, dotado de poder legislativo, que busca o significado, o sentido e o alcance da norma constitucional para o fim de, fixando-lhe o conteúdo concreto, complementá-la e, conseqüentemente, dar-lhe aplicação". 35 Todo e qualquer ato legislativo que tenha por objetivo a aplicação direta de disposição constitucional configura uma interpretação constitucional. Essa espécie de interpretação cabe, precipuamente, ao Poder Legislativo, por meio da edição de leis ou atos normativos que visem aplicar preceito constitucional. Porém, o Poder Executivo também participa da interpretação constitucional legislativa, seja no processo legislativo, pela iniciativa de lei, sanção ou veto, ou ainda, através da edição de medidas provisórias ou leis delegadas que tenham por objetivo a aplicação direta de dispositivo constitucional.

Essa interpretação legislativa volta-se, diretamente, para a aplicação de disposições constitucionais, mas é limitada pelo texto e espírito da Constituição. É uma interpretação mutável, uma vez que pode ser alterada por norma posterior da mesma natureza, e não é definitiva, posto que, pode ser objeto de controle de constitucionalidade. Como as leis são dotadas de generalidade e coercibilidade, essa interpretação tem força vinculante.

Em se tratando de normas constitucionais de eficácia limitada, sejam elas programáticas ou institutivas, a interpretação constitucional legislativa é imprescindível, de modo que ela integra a eficácia dessas normas constitucionais. Sem a lei integradora, o preceito constitucional restará inerte. Nas normas de eficácia contida, o próprio poder constituinte

\footnotetext{
${ }^{34}$ FERRAZ, Anna Cândida da Cunha. Op. cit., p. 54.

${ }^{35}$ FERRAZ, Anna Cândida da Cunha. Op. cit., p. 65.
} 
originário permite que o legislador, ao interpretar o dispositivo, restrinja o seu âmbito de eficácia e aplicabilidade.

A interpretação constitucional judicial é apontada pela doutrina como a de maior relevância dentre as espécies de interpretação orgânica. É aquela realizada pelo Poder Judiciário que, no exercício de sua função jurisdicional, aplica a Constituição no caso concreto, seja mediante a aplicação pura e simples de dispositivo constitucional com o intuito de solucionar a lide, seja realizando o controle de constitucionalidade das leis ou atos normativos.

Em razão do princípio constitucional da inafastabilidade do Poder Judiciário, não pode o juiz, quando provocado, deixar de solucionar o litígio. Dessa forma, a interpretação constitucional é obrigatória e exercida com fundamento direto na Constituição. É uma interpretação definitiva para as partes que figuram na lide, mas pode ser modificada na apreciação de outro litígio. Essa interpretação também deve observar os limites impostos pelo texto e espírito da Constituição.

"Nítido o papel de mutação constitucional da interpretação judicial, que sem alterar a letra ou o espírito da Constituição, lhe dá novo significado ou alcance para, aplicando-a, torná-la o que se pretende que ela seja: um documento vivo e efetivamente cumprido". ${ }^{36}$ Um exemplo marcante foi a doutrina brasileira do habeas corpus, na qual o Supremo Tribunal Federal conferiu interpretação ampla ao conceito de habeas corpus contido na Constituição de 1891. Assim, o remédio constitucional, originariamente utilizado na tutela do direito de locomoção, passou a ser admitido na proteção de qualquer lesão à direito individual praticado por abuso de autoridade pública.

A interpretação constitucional administrativa é, de maneira geral, atribuída aos órgãos do Poder Executivo, que devem ajustar seus atos, resoluções e disposições à supremacia da Constituição. O administrador, no momento da realização de um ato administrativo, deverá verificar a sua

\footnotetext{
${ }^{36}$ FERRAZ, Anna Cândida da Cunha. Op. cit., p. 130.
} 
constitucionalidade. Dessa forma, os órgãos do poder executivo, se interpretarem pela inconstitucionalidade do ato, poderão deixar de realizálo, assim como podem deixar de regulamentar lei que considerem inconstitucional. A possibilidade de ação direta de inconstitucionalidade não impede o exercício desse controle de constitucionalidade por parte do Poder Executivo.

Não raro, os poderes legislativo e judiciário também desenvolvem essa interpretação constitucional administrativa, quando exercem atribuições de natureza administrativa conferidas pela Constituição.

A interpretação constitucional administrativa configura processo de mutação constitucional sempre que, atuando para concretizar, integrar e aplicar a Constituição, conduz, permite e possibilita a transformação do sentido, do significado e do alcance das disposições da lei fundamental, amoldando-a a realidades novas, a situações novas, novas necessidades sociais. ${ }^{37}$

São formas de interpretação constitucional não-orgânica: a interpretação autêntica, a interpretação popular e a interpretação doutrinária.

A interpretação autêntica é aquela realizada pelo próprio órgão que editou a disposição normativa a ser interpretada. Em sede de interpretação constitucional não pode ser realizada, uma vez que o poder constituinte originário, logo após a elaboração da Constituição, se exauriu. Entretanto, há quem defenda que, existe sim, interpretação autêntica da Constituição quando realizada pelo poder competente para a reforma da Constituição. ${ }^{38}$

A interpretação constitucional popular é aquela realizada pelo próprio povo e também pelas forças vivas da comunidade, a saber, os grupos de pressão, os partidos políticos, a opinião pública, entre outros. A própria Constituição prevê mecanismos para isso, seja através do referendo, plebiscito ou pela iniciativa popular. Assim, essa interpretação pode conduzir à revogação ou alterações do texto constitucional, como também

\footnotetext{
${ }^{37}$ FERRAZ, Anna Cândida da Cunha. Op. cit., p. 157.

${ }^{38}$ Celso Ribeiro Bastos, Gomes Canotilho, Jorge Miranda e Carlos Maximiliano defendem a interpretação constitucional autêntica. Por outro lado Luís Roberto Barroso, Anna Cândida Ferraz e José Afonso da Silva acreditam não ser possível a mencionada interpretação em sede constitucional. In BARROSO, Luís Roberto. Op. cit., p. 119.
} 
pode acarretar mudança no sentido da norma constitucional, sem sua modificação formal.

A interpretação doutrinária é aquela realizada pela ciência jurídica e por juristas. É uma interpretação indireta e não vinculante. Exerce papel importante, na medida em que, de forma indireta, influencia no processo de mudança da Constituição pela interpretação judicial, administrativa e legislativa.

\title{
1.6.4. Mutação por Interpretação Constitucional
}

A interpretação constitucional é um importante meio de mutação constitucional. Ocorre quando o intérprete, na aplicação de um dispositivo constitucional, lhe confere um sentido novo ou um sentido mais abrangente, atingindo situações antes não contempladas pela norma, sem que haja qualquer modificação na sua redação. Destaca-se que o limite dessa interpretação é o próprio texto da Constituição, pois que, nas constituições rígidas, as alterações do texto que não observem o procedimento previsto serão declaradas inconstitucionais.

Anna Cândida da Cunha Ferraz enumera, de forma não taxativa, as hipótese de mutação constitucional por interpretação constitucional:

\begin{abstract}
Mutação pela via interpretativa é claramente percebível numa das situações seguintes: a) quando há um alargamento do sentido do texto constitucional, aumentando-se-lhe, assim, a abrangência para que passe a alcançar novas realidades; b) quando imprime sentido determinado e concreto ao texto constitucional; c) quando se modifica interpretação anterior e se lhe imprime novo sentido, atendendo à evolução da realidade constitucional; d) quando há adaptação do texto constitucional à nova realidade social, não prevista no momento da elaboração da Constituição; e) quando há adaptação do texto constitucional para atender exigências do momento da aplicação da Constituição; f) quando se preenche, por via interpretativa, lacunas do texto constitucional. ${ }^{39}$
\end{abstract}

Alguns fatores podem interferir na interpretação constitucional como processo de mutação constitucional, a saber, o caráter sintético, genérico e esquemático das normas constitucionais, a linguagem do texto

\footnotetext{
${ }^{39}$ FERRAZ, Anna Cândida da Cunha. Op. cit., p. 58-9.
} 
constitucional com termos vagos, sem significado definido, a presença de lacunas ou obscuridades e o elemento político das normas constitucionais.

Conforme exposto no início do capítulo, a mutação constitucional é um fenômeno necessário para a melhor adaptação da Constituição às evoluções da sociedade. Entretanto, quanto mais elástico for o processo de interpretação, maiores serão os riscos de desvirtuamento do texto constitucional e dos princípios fundamentais que embasam a Constituição. Assim, as mutações constitucionais via processo interpretativo devem ser realizadas, mas com ponderação, dentro dos limites constitucionais, sob pena de afetar o núcleo essencial intangível da Constituição.

\subsection{Costume Constitucional como forma de Mutação Constitucional}

O termo costume jurídico refere-se à prática reiterada de uma conduta, não prevista em lei, que produza efeitos jurídicos. Desse conceito pode-se extrair dois elementos: o objetivo e o subjetivo. O primeiro representa a observância repetida, habitual e uniforme de determinado comportamento. O elemento subjetivo consiste na convicção generalizada da necessidade e obrigatoriedade daquele ato. Caso não sejam preenchidos todos esses requisitos, a conduta será considerada mero uso ou prática jurídica.

O costume é um ato primário, de formação espontânea e voluntária. Possui caráter definitivo, mas pode ser revogado ou suprimido por lei. A doutrina costuma enumerar três espécies de costumes jurídicos. O costume secundum legem é aquele em que a prática constitucional encontra-se prevista na lei, assumindo o costume uma função interpretativa. Já os costumes praeter legem possuem função integrativa, preenchendo as lacunas da lei ou complementando-a. E, por fim, há uma terceira hipótese de costume jurídico, o contra legem, que é manifestado por uma prática oposta à disposição do texto legal, possuindo uma função derrogatória. Anna Cândida da Cunha Ferraz inclui nessa última espécie não apenas os usos e práticas contrários à lei, mas também o desuso, isto é, a 
inobservância constante e prolongada do texto escrito. A doutrina mais cautelosa entende que o desuso não atinge a eficácia da norma, podendo ser aplicada a qualquer tempo. Porém, há quem defenda que o desuso seria sim, um costume contra legem, gerando uma mutação inconstitucional. ${ }^{40}$ Destaca-se que a doutrina majoritária sequer admite a possibilidade de costumes contra legem.

No âmbito constitucional, uma parte da doutrina nega a existência de costumes constitucionais frente às constituições rígidas, invocando a concepção de supremacia das disposições constitucionais. Todavia, o entendimento predominante indica a existência de costumes secundum constitutionem e praeter constitutionem e a rejeição dos costumes contra constitutionem. $^{41}$ Dessa forma, os costumes constitucionais possuem importante papel na interpretação, integração e complementação das normas constitucionais, mas não têm o condão de revogar uma disposição constitucional. Seja interpretativo ou integrativo, o costume não substitui a norma constitucional, não podendo reformá-la.

Há casos em que o Texto Constitucional é uma pura hipótese, sendo a realidade da Constituição muito mais representada pelas praxes e costumes que cercam a sua aplicação. A Constituição material, efetiva, de um Estado pode mais facilmente ser identificada nos costumes e praxes constitucionais do que no texto propriamente dito. [...] A doutrina aceita, sem maiores reservas, o costume secundum constitutionem e praeter constitutionem, mas rejeita, por inadmissível, o costume constitucional contra constitutionem. ${ }^{42}$

O costume constitucional será um meio eficaz para a realização de mutações constitucionais, quando, interpretando ou integrando a norma constitucional, produza mudanças no seu sentido, alcance ou significado, sem alterar a letra e o espírito da Constituição. Essa alteração informal da Constituição via costume constitucional tem inegável importância no

\footnotetext{
${ }^{40}$ Favorável a posição de que o desuso não seria um costume contra legem encontramos Carlos Maximiliano. Já Carbone Carmelo e Biscaretti di Ruffia defendem a possibilidade do desuso como costumes constitucionais, e portanto, com caráter revogatório. Apud Ferraz, Anna Cândida da Cunha. Op. cit., p. 180-1.

${ }^{41}$ Ferraz, Anna Cândida da Cunha. Op. cit., p. 180-1; BULOS, Uadi Lammêgo. Op. cit., p. 177-8; BARROSO, Luís Roberto. Op. cit., p. 145.

${ }^{42}$ Barroso, Luís Roberto. Op. cit., p. 145.
} 
tocante ao funcionamento e relacionamento entre os poderes, já que é extremamente difícil reduzir essas relações políticas a regras e fórmula rígidas.

\subsection{Mutações Inconstitucionais}

As mutações inconstitucionais verificam-se quando ocorrem alterações informais da Constituição que impliquem em contradição com texto ou espírito constitucional ou, ainda, que reduzam a eficácia de dispositivos constitucionais. De acordo com Anna Cândida da Cunha Ferraz, as mutações inconstitucionais se dividem em dois tipos de processos, a saber, os processos manifestamente inconstitucionais, que mudam a Constituição contra a sua letra ou espírito, e os processos anômalos, representados pela inércia dos poderes constitucionais, o desuso de preceitos e disposições e pela mudança tácita da Constituição. ${ }^{43}$

\subsubsection{Processos Anômalos de Mutação}

Configura-se a inércia no plano constitucional quando uma disposição constitucional deixa de ser plenamente aplicada, de forma intencional e provisória, por quem tinha competência constitucional de lhe dar cumprimento e execução. Não há um prazo exato para a sua configuração, pois que existem normas constitucionais que reclamam imediata aplicabilidade, mas outras não.

Esse processo de inércia pode alterar o texto constitucional na medida em que paralisa a eficácia do dispositivo constitucional, operando uma verdadeira mutação inconstitucional. Essa inércia, além de não contribuir para a evolução constitucional, acarreta a descrença da população na Constituição.

O desuso constitucional revela uma inobservância uniforme, consciente, reiterada e pública, por um longo período de tempo, de uma norma constitucional. Difere da inércia, pois o desuso pressupõe o ânimo

\footnotetext{
${ }^{43}$ Ferraz, Anna Cândida da Cunha. Op. cit., p. 213.
} 
definitivo de que o dispositivo jamais será reativado. Esse desuso pode se referir à não-aplicação de uma norma constitucional, à desativação de institutos ou instituições constitucionais, ou à não-realização de determinado ato exigido pela Constituição.

O desuso constitucional implica uma contrariedade reflexa da Constituição, de modo que a disposição constitucional restará inerte. Dessa forma, configura uma mutação inconstitucional. Anna Cândida da Cunha Ferraz defende que o desuso, quando tem o intuito de adaptar a Constituição às novas exigências da sociedade, é admissível. Todavia, destaca que a reforma constitucional seria o meio adequado para a realização de alterações desse tipo. ${ }^{44}$

A mudança tácita da Constituição tem como base a mudança formal da Constituição. Pode ocorrer em duas situações: quando é realizada uma reforma constitucional que não indica com clareza e precisão o texto alterado, ou quando a reforma indica o texto alterado, mas essa modificação contraria dispositivos existentes na Constituição. São defeitos de técnica legislativa que podem provocar mudanças imprevisíveis na Constituição. De acordo com Anna Cândida da Cunha Ferraz, é "inteiramente indesejável, vez que não se destina a adaptar a Constituição à realidade concreta ou se quer dar vida à norma constitucional, mas ao contrário, é fator de perturbação na vida constitucional". ${ }^{45}$

\subsubsection{Mutações Manifestamente Inconstitucionais}

São mutações manifestamente inconstitucionais as mudanças na Constituição que não respeitem os limites constitucionais, violando o texto e o espírito da Constituição. Pode ser verificada quando a mutação por interpretação legislativa, administrativa ou judicial contrariar disposição constitucional, ou ainda, nos casos de mutações por costumes contra constitutionem.

\footnotetext{
${ }^{44}$ Ferraz, Anna Cândida da Cunha. Op. cit., p. 237.

${ }^{45}$ FERRAZ, Anna Cândida da Cunha. Op. cit., p. 242.
} 
Essas mutações manifestamente inconstitucionais podem "a) contrariar parcialmente a Constituição; b) ab-rogar ou derrogar determinada norma constitucional; c) suspender, temporariamente a eficácia de normas constitucionais; d) produzir rupturas no ordenamento constitucional; e) provocar mudança total da Constituição". ${ }^{46}$ Em razão dessa série de conseqüências desastrosas que as mutações inconstitucionais podem causar, elas devem ser afastadas do nosso ordenamento jurídico. Entretanto, é comum, na prática constitucional, a sua ocorrência.

Anna Cândida da Cunha Ferraz aponta algumas medidas que poderiam minimizar a ocorrência dessas mutações inconstitucionais, entre elas, a fixação de prazos para a efetivação das normas nas matérias mais relevantes e uma respectiva sanção para o seu descumprimento, a efetiva responsabilização dos detentores do poder diante da inobservância de um dever constitucional, a ampliação do alcance dos remédios constitucionais e o fortalecimento dos órgãos de controle. ${ }^{47}$

Em síntese, as mutações constitucionais são mecanismos necessários para que a Constituição se mantenha viva e acompanhe as evoluções da sociedade. Todavia, os limites impostos pela própria Constituição devem ser observados e respeitados, para que não gerem verdadeiras mutações inconstitucionais.

As mutações, quando constitucionais, têm um fundamento que não pode ser ignorado, o de promover mudanças necessárias e perfeitamente admitidas, sem a necessidade de recorrer-se aos processos formais de alteração, promanados daquelas reformas, muitas vezes despropositadas, sem previsibilidade técnica e sem visão de futuro. ${ }^{48}$

\footnotetext{
${ }^{46}$ FERRAZ, Anna Cândida da Cunha. Op. cit., p. 245.

${ }^{47}$ FERRAZ, Anna Cândida da Cunha. Op. cit., p. 257.

${ }^{48}$ BULOS, Uadi Lammêgo. Op. cit., p. 139.
} 


\section{CAPÍTULO 2}

\section{DO CONTROLE DE CONSTITUCIONALIDADE}

O controle de constitucionalidade das leis é, sem dúvida alguma, um dos mais importantes pontos no direito constitucional atual. É um tema complexo e não é a minha pretensão esgotá-lo neste trabalho, apenas abordarei alguns aspectos relevantes, necessários para uma melhor compreensão do capítulo seguinte.

\subsection{Noções Fundamentais}

O controle de constitucionalidade é um instrumento importante para a garantia da unidade da Constituição, afastando do mundo jurídico as normas que com ela não são compatíveis. Refere-se à verificação da adequação de um ato normativo ou do processo de sua elaboração face à Constituição, sendo inconstitucional o ato normativo que não observe o conteúdo das normas constitucionais ou mesmo as regras formais estabelecidas na lei maior.

A inconstitucionalidade constitui vício aferido no plano da validade da norma. Desta forma a norma inconstitucional é inválida, e consequientemente também é desprovida de eficácia, não devendo ser aplicada ao caso concreto. Dessa forma, "aplicar uma norma inconstitucional significa deixar de aplicar a Constituição". ${ }^{49}$

A decisão que reconhece a inconstitucionalidade de lei ou ato normativo tem natureza declaratória, isto é, reconhece uma situação préexistente de nulidade. Como conseqüência, seus efeitos atuam retroativamente, desde o momento da entrada em vigor da lei ou ato normativo no mundo jurídico. Porém, em alguns casos, excepcionalmente, admite-se a supressão ou atenuação do caráter retroativo do

\footnotetext{
${ }^{49}$ BARROSO, Luís Roberto. O Controle de Constitucionalidade no Direito Brasileiro: exposição sistemática da doutrina e análise crítica da jurisprudência. $3^{\text {a }}$ ed. rev. e atual. - São Paulo: Saraiva, 2008, p. 1.
} 
pronunciamento de inconstitucionalidade visando à proteção da boa-fé, da justiça e da segurança jurídica.

Barroso aponta duas premissas constitucionais para a realização desse controle. A primeira delas é a supremacia da Constituição, de modo que a Constituição ocupa uma posição hierarquicamente superior no ordenamento jurídico, servindo como fundamento de validade das demais normas. A segunda premissa é a rigidez constitucional, existindo um processo mais complexo para a elaboração das normas constitucionais. ${ }^{50}$

Toda espécie normativa que é editada pelo poder público é dotada de presunção de constitucionalidade, isto é, presunção de que nasceu de acordo com a Constituição e que por isso deve ser preservada. No entanto, essa é uma presunção relativa, uma vez que as leis e os atos normativos podem ser objeto de controle de constitucionalidade. De acordo com o Supremo Tribunal Federal, as únicas normas que possuem presunção absoluta de constitucionalidade são as normas constitucionais originárias. ${ }^{51}$

\subsection{Sistema Brasileiro de Controle de Constitucionalidade}

A Constituição Brasileira de 1824 não previa um mecanismo de controle de constitucionalidade. Na República, ele foi introduzido no sistema jurídico brasileiro pela Constituição Provisória de 1890 e pelo Decreto 848, de 11 de Outubro de 1890. Em 1891 o tema recebeu tratamento constitucional, com a adoção de um sistema importado dos Estados Unidos, no qual se extraía competência das Justiças dos Estados e da União para se pronunciarem a respeito da invalidade da lei face a Constituição. O controle era exercido de modo incidental, difuso e com eficácia restrita às partes. Destaca-se que, diferentemente do que foi implantado no Brasil, no modelo norte-americano as decisões da Suprema Corte a respeito da constitucionalidade vinculam os demais órgãos do Poder Judiciário.

\footnotetext{
${ }^{50}$ BARROSO, Luís Roberto. Op.cit, p. 1-2.

${ }^{51} \mathrm{ADI} n^{\circ}$. 815- DF.
} 
Na Constituição de 1934, reconheceu-se a possibilidade de o Senado Federal conferir efeito vinculante às decisões do Supremo Tribunal Federal proferidas em controle difuso de constitucionalidade, isto é, suspender a eficácia de uma lei declarada inconstitucional. A mencionada Constituição estabeleceu ainda que, em nome da presunção de constitucionalidade das normas, os tribunais só poderiam declarar a inconstitucionalidade de uma norma no caso concreto por maioria absoluta. É também na Constituição de 1934 que nasce, no direito brasileiro, uma espécie de controle de constitucionalidade concentrado, sob o nome de representação interventiva, somente possuindo legitimidade para propô-la o Procurador-Geral da República.

A Emenda Constitucional ño. 16/65 à Constituição de 1946 instituiu a representação de inconstitucionalidade, um mecanismo de fiscalização abstrata e concentrada pelo Supremo Tribunal Federal. Tinha o objetivo de avaliar, em tese, a constitucionalidade de uma norma, desvinculada de qualquer interesse pessoal. Apenas o Procurador-Geral da República tinha legitimidade para apresentá-la e a eficácia desta decisão era contra todos erga omnes. Juntamente com esse mecanismo, convivia o controle difuso. A Constituição de 1967 não inovou. Já a Constituição de 1969 (Emenda Constitucional $n^{\circ} 1$, de 17/10/1969) criou a ação direta em âmbito estadual, limitada à hipótese de intervenção do Estado no Município.

A Constituição de 1988 manteve o sistema híbrido, combinando o controle por via incidental e difuso (sistema americano) com o controle por via principal e concentrado, inaugurado pela Emenda Constitucional $\mathrm{n}^{\circ}$. 16/65 (sistema continental europeu) no mesmo ordenamento. A citada Constituição também trouxe inovações importantes: ampliou os legitimados para a propositura da ação direta de inconstitucionalidade, introduziu a ação de inconstitucionalidade por omissão e o mandado de injunção, criou a argüição de descumprimento de preceito fundamental e recriou a representação de inconstitucionalidade em âmbito estadual. 
O controle de constitucionalidade no Brasil é predominantemente jurisdicional e repressivo, conferindo ao Poder Judiciário a última palavra acerca de questões constitucionais depois que o ato ingressa no mundo jurídico. Mas existe também o controle político, exercido tanto pelo poder legislativo quanto pelo poder executivo, seja por meio do veto do Presidente da República no processo legislativo, seja pelo exame do projeto de lei na Comissão de Constituição e Justiça, entre outros meios.

\subsection{Controle Concentrado/Abstrato e Efeitos da Decisão}

O controle abstrato é realizado por meio de ação autônoma, cujo objeto principal é a questão da inconstitucionalidade, não existindo qualquer vinculação a um caso concreto. O objetivo desse controle é a invalidação da lei a fim de garantir a segurança das relações jurídicas, que não podem ser pautadas em normas inconstitucionais. É um processo objetivo, no qual a legitimidade ativa é restrita.

A Constituição Federal prevê hipótese de realização dessa modalidade de controle. São elas: ação direta de inconstitucionalidade (artigo 102, I, a), ação de inconstitucionalidade por omissão (artigo 103, § $2^{\circ}$ ), ação declaratória de inconstitucionalidade (artigo 102, I, a), argüição de descumprimento de preceito fundamental (artigo 102, $\S 2^{\circ}$ ) e a representação de inconstitucionalidade no âmbito estadual (artigo 125, § $\left.2^{\circ}\right)$.

Essas ações autônomas que objetivam o controle da constitucionalidade da lei são propostas perante um único órgão jurisdicional indicado na Constituição. As ações que possuem como parâmetro de constitucionalidade a Constituição Federal são de competência originária do Supremo Tribunal Federal, a quem compete a guarda da nossa Carta Maior. Já o controle que afere a compatibilidade de atos normativos com a Constituição Estadual é atribuído ao respectivo tribunal de justiça. 
A Ação Direta de Inconstitucionalidade tem a finalidade de retirar do ordenamento jurídico lei ou ato normativo federal ou estadual incompatível com a ordem constitucional. Em regra, essa ação terá como objeto os atos normativos primários federais ou estaduais aptos a inovar na ordem jurídica, desde que dotados de generalidade, abstração, existência e edição posterior ao texto constitucional. ${ }^{52}$ Segundo Clèmerson Merlin Clève, podem ser objeto de ação direta de inconstitucionalidade as emendas constitucionais, os atos normativos formalmente legislativos (leis complementares, leis ordinárias, leis delegadas, medidas provisórias, decretos legislativos, etc.), os tratados internacionais devidamente internacionalizados e as leis distritais que tenham como tema matéria de competência estadual. $^{53}$

A ação direta de inconstitucionalidade deverá ser proposta perante o Supremo Tribunal Federal. O artigo 103 da Constituição apresenta o rol de legitimados para a sua propositura. O Presidente da República, a Mesa do Senado Federal, a Mesa da Câmara dos Deputados, o Procurador-Geral da República, o Conselho Federal da Ordem dos Advogados do Brasil e partido político com representação no Congresso Nacional são legitimados universais, isto é, pela posição institucional que ocupam, não precisam de outro interesse além da confirmação da constitucionalidade ou inconstitucionalidade da norma. Já a Mesa da Assembléia Legislativa ou da Câmara Legislativa do Distrito Federal, o Governador do Estado ou do Distrito Federal, confederações sindicais e entidades de classe de âmbito nacional são legitimados especiais, uma vez que é necessária a demonstração da pertinência temática, isto é, da relação entre o objeto da ação e o interesse que representam. Destaca-se que essa classificação em

\footnotetext{
${ }^{52} \mathrm{O}$ requisito de posteridade à constituição deve-se ao fato de o Supremo entender que leis e atos normativos anteriores e incompatíveis com a Constituição superveniente são revogadas. É questão, portanto, de recepção ou revogação. Isto porque entende a jurisprudência que os atos normativos anteriores à Constituição e incompatíveis com ela são tacitamente revogáveis, não se tratando de inconstitucionalidade superveniente.

53 CLÉVE, Clèmerson Merlin. A Fiscalização Abstrata da Constitucionalidade no Direito Brasileiro. $2^{\mathrm{a}}$ ed., São Paulo: Revista dos Tribunais, 2000.
} 
legitimados universais e especiais é uma construção jurisprudencial do Supremo Tribunal Federal.

A decisão que declara a inconstitucionalidade da lei ou ato normativo somente poderá ser proferida por maioria absoluta. É dotada de eficácia erga omnes e vincula os demais membros do Poder Judiciário sem que seja necessária a intervenção do Senado Federal, pois a simples publicação da decisão já faz com que a norma inconstitucional perca a sua força.

Como regra geral, essa decisão produzirá efeitos ex tunc. Todavia o artigo 27 da lei $\mathrm{n}^{\circ}$. 9868/99 conferiu ao Supremo a possibilidade de determinar a extensão dos efeitos da declaração de inconstitucionalidade. Dessa forma, por maioria de dois terços dos ministros e tendo em vista a segurança jurídica ou o excepcional interesse público, poderá a norma não ser válida a partir do trânsito em julgada da decisão, ou posteriormente ao acórdão ou ainda em qualquer momento entre a vigência da norma e o trânsito em julgado do acórdão.

O controle de constitucionalidade por via de ação direta também pode ser exercido no âmbito estadual. É previsto no artigo $125, \S 2^{\circ} \mathrm{da}$ Constituição Federal sob a denominação de representação de inconstitucionalidade. Refere-se à verificação de compatibilidade de leis e atos normativos municipais, distritais ou estaduais face à Constituição Estadual ou a Lei Orgânica do Distrito Federal, sendo competente para o processamento e julgamento o Tribunal de Justiça do respectivo ente federativo.

A Ação Direta de Inconstitucionalidade por Omissão é uma novidade trazida pela Constituição de 88 , visando combater a inércia do Estado em legislar ou regulamentar matéria estipulada na Constituição. O objeto dessa ação são normas constitucionais de eficácia limitada, isto é, aquelas que exigem a elaboração de normas que as regulamentem. A 
inconstitucionalidade, nestes casos, reside em um deixar de agir do Estado quando a Constituição estabelecia uma atuação positiva, o que resulta em descumprimento de ordem constitucional específica. Os legitimados a sua propositura são os mesmos da ação direta de inconstitucionalidade. Ao Supremo Tribunal Federal compete o seu julgamento, cuja decisão de procedência apenas tem o condão de notificar o órgão omisso para que ele adote as medidas necessárias ${ }^{54}$.

A Ação Declaratória de Constitucionalidade foi introduzida na Constituição pela Emenda Constitucional n ${ }^{\circ}$. 3/93, com o objetivo de afastar a insegurança jurídica ou o estado de incerteza sobre a validade de lei ou ato normativo federal. A legitimidade ativa dessa ação, inicialmente restrita ao Presidente da República, ao Presidente do Senado Federal, ao Presidente da Câmara dos Deputados e ao Procurador Geral da República, foi ampliada pela Emenda Constitucional $\mathrm{n}^{\circ} .45 / 04$, passando a abranger todo o rol do artigo 103 da Constituição. O seu processamento e julgamento compete ao Supremo Tribunal Federal.

O artigo $102, \S 1^{\circ}$, da Constituição, que prevê a Argüição de Descumprimento de Preceito Fundamental, é uma norma constitucional de eficácia limitada, regulamentada, portanto, pela lei no ${ }^{\circ}$ 9882/99. A competência para o seu processamento e julgamento é do Supremo Tribunal Federal. A legitimidade ativa para a sua propositura também se encontra no rol do artigo 103 da Constituição.

Cabe ao Supremo Tribunal Federal identificar quais são os preceitos fundamentais, uma vez que a mencionada lei não trata do assunto. Segundo Barroso, existem normas constitucionais que inegavelmente são preceitos fundamentais: os princípios fundamentais (artigos $1^{\circ}$ a $4^{\circ}$ ), os direitos

\footnotetext{
${ }^{54}$ Essa limitação decorre do princípio da separação dos poderes. No entanto essa posição nãoconcretista está passando por transformações no julgamento da ADI por omissão nº 3682.
} 
individuais (artigos $5^{\circ}$ e seguintes), os princípios constitucionais sensíveis (artigo 34, VII) e as cláusulas pétreas (artigo 60, $\left.\$ 4^{\circ}\right) .^{55}$

A argüição pode ser autônoma ou incidental, e tem por objeto evitar ou reparar lesão provocada por ato do Poder Público, incluindo as três esferas da federação. Também será cabível frente a relevante controvérsia constitucional sobre lei ou ato normativo federal, estadual ou municipal, incluídos os anteriores à Constituição. Essa argüição tem caráter residual, só sendo admitida quando esgotados os outros meios de controle jurisdicional de constitucionalidade.

Em regra, a decisão nessa argüição de descumprimento de preceito fundamental tem eficácia ex tunc, erga omnes e efeito vinculante aos demais órgãos do poder público. Mas, por motivos de segurança jurídica e de excepcional interesse social, poderá o Supremo Tribunal Federal restringir a extensão dos efeitos. As autoridades ou órgãos responsáveis pelos atos praticados serão comunicados da decisão, e serão fixadas as condições, a interpretação e a aplicação adequada do preceito fundamental. Se houver descumprimento da decisão, caberá reclamação ao Supremo Tribunal Federal.

Existe também a Ação Direta Interventiva, que deve ser proposta pelo Procurador-Geral da República perante o Supremo Tribunal Federal nos casos em que for necessária a intervenção federal por inobservância dos princípios constitucionais sensíveis. É uma modalidade de controle concentrado, por meio de ação autônoma, mas concreto, uma vez que o objeto principal da demanda é o conflito entre o Estado-membro e a União.

\subsection{Controle Difuso/Concreto e Efeitos da Decisão}

O controle difuso de constitucionalidade não encontra disposição expressa na Constituição. Todavia é possível extrair do artigo 102 inciso III essa possibilidade, uma vez que o citado dispositivo prevê a competência do

\footnotetext{
${ }^{55}$ BARROSO, Luís Roberto. Op.cit, p. 267.
} 
Supremo Tribunal Federal para o julgamento, mediante recurso extraordinário, das causas decididas em única ou última instância, quando a decisão recorrida contrariar dispositivo da Constituição, declarar inconstitucionalidade de lei ou tratado federal, julgar válido ato ou lei de governo local contestado em face à Constituição ou julgar válida lei local contestada em face de lei federal. A partir dessa disposição, pode-se deduzir que qualquer juiz ou tribunal pode aferir a constitucionalidade de um ato normativo. Ressalte-se que o Supremo Tribunal Federal também exerce controle de constitucionalidade difuso nas causas de sua competência originária e nas oriundas de recurso ordinário.

Esse controle difuso é realizado por qualquer juiz ou tribunal no exercício normal da função jurisdicional, dentro do julgamento de um caso concreto. Assim, o objeto principal da demanda não é a inconstitucionalidade do ato normativo, mas sim os interesses individuais envolvidos no processo. A questão constitucional é uma questão prejudicial, cujo julgamento é necessário para a resolução do objeto principal da lide.

A legitimidade para argüir essa inconstitucionalidade é ampla, sendo facultado ao autor da ação, ao réu e ao Ministério Público contestarem a aplicação da norma inconstitucional, ou ao próprio juiz ou tribunal de ofício.

Esse controle, de caráter difuso, afeta qualquer instância ou órgão do Poder Judiciário, que poderá deixar de aplicar uma lei federal, estadual ou municipal, bem como atos normativos ainda que secundários, no caso concreto, se considerarem incompatível com a Constituição Federal.

Em primeira instância, o juiz, de forma monocrática, simplesmente deixa de aplicar a norma por considerá-la inconstitucional. Já em segunda instância deverá ser observado o princípio constitucional da reserva de plenário, previsto no artigo 97 da Constituição, pelo qual a inconstitucionalidade de uma lei só pode ser declarada pela maioria absoluta dos membros do tribunal ou de seu órgão especial, onde exista. Assim, ao tribunal fracionário é submetida a questão. Se este não acolher a 
inconstitucionalidade, o processo segue regularmente, mas, se acolhe a argüição de inconstitucionalidade, lavrará acórdão nesse sentido e encaminhará a questão para ser submetida ao tribunal pleno ou órgão especial, ficando o processo suspenso no órgão fracionário. $\mathrm{O}$ tribunal deliberará a respeito, observando o quorum de maioria absoluta. Declarada ou não a inconstitucionalidade, o julgamento será retomado no órgão fracionário, tendo como premissa lógica à decisão proferida pelo tribunal.

O Supremo Tribunal Federal, recentemente, editou a Súmula Vinculante número 10, deixando clara a obrigatoriedade da observância dessa reserva de plenário não apenas quando o tribunal declara expressamente a inconstitucionalidade de uma norma, mas também quando deixa de aplicá-la por considerá-la inconstitucional.

Destaca-se que, de acordo com o artigo 481, parágrafo único, do Código de Processo Civil, não será necessária a submissão da argüição de inconstitucionalidade ao órgão especial ou pleno quando já houver pronunciamento do plenário do Supremo Tribunal Federal sobre a questão. De acordo com Gilmar Ferreira Mendes, "tal posição sinaliza com (ainda que tímida) a equiparação entre efeitos da declaração de inconstitucionalidade em sede de controle incidental com os efeitos da declaração em controle concentrado". 56

Em razão de o controle difuso de constitucionalidade estar vinculado a um caso concreto, os efeitos da decisão limitam-se às partes envolvidas. Ressalte-se que a decisão transitada em julgado será acobertada pelo manto da coisa julgada no que tange à parte dispositiva, o que não inclui o reconhecimento ou não da constitucionalidade, que é questão prejudicial. A decisão produzirá efeitos ex tunc, em razão do reconhecimento de nulidade pré-existente. No entanto, em casos excepcionais poderá o órgão jurisdicional limitar essa eficácia retroativa.

\footnotetext{
${ }^{56}$ MENDES, Gilmar Ferreira; COELHO, Inocêncio Mártire; BRANCO, Paulo Gustavo Gonet. Curso de Direito Constitucional. $2^{\mathrm{a}}$ ed. rev. e atual. São Paulo: Saraiva, 2008, p.1072.
} 


\subsection{Papel do Senado Federal no Controle Difuso}

O Senado Federal tem competência, no controle difuso de constitucionalidade, de suspender, parcial ou totalmente, a execução de lei declarada inconstitucional por decisão final do Supremo Tribunal Federal. Esse papel do Senado Federal é fruto do receio do constituinte em atribuir poderes demasiados ao Judiciário no controle de constitucionalidade.

Em 1891, o Brasil importou o modelo de controle de constitucionalidade difuso norte-americano com uma sensível diferença, pois que nos Estados Unidos as declarações de inconstitucionalidade da Suprema Corte vinculavam todos os demais órgãos do Poder Judiciário, enquanto que aqui, mesmo quando decidido pelo Supremo Tribunal Federal, as declarações de inconstitucionalidade produziam efeitos apenas entre as partes. Assim, toda vez que o Supremo Tribunal Federal entendia pela inconstitucionalidade de uma norma no caso concreto, todas as demais pessoas atingidas pela mesma lei teriam que ingressar com ações individuais para que the fossem aplicados os efeitos da declaração de inconstitucionalidade. Isso gerou, ao longo do período da Primeira República, uma abundância de demandas idênticas, discutindo temas já consolidados pelo Tribunal. Note-se que ainda não havia previsão de controle concentrado.

Diante dessa necessidade de concessão de eficácia geral às decisões de inconstitucionalidade e com a resistência de se atribuir poderes excessivos ao Poder Judiciário, o constituinte previu na Constituição de 1934 a possibilidade de o Senado Federal conferir efeitos erga omnes às declarações de inconstitucionalidade proferidas pelo STF em controle difuso, disposição esta mantida pelas constituições posteriores.

Assim, caso o Supremo Tribunal Federal decida, por maioria dos seus membros, não aplicar a lei ou ato normativo em um caso concreto por considerá-la inconstitucional, deverá comunicar ao Senado, que poderá 
editar resolução atribuindo efeito vinculante com eficácia ex tunc àquela decisão. ${ }^{57}$

A Constituição prevê essa atribuição, mas não estipula prazo, por entender tratar-se de uma atividade discricionária, sujeitando-se ao juízo de conveniência e oportunidade da casa legislativa. Destaca-se que essa atribuição do Senado Federal só é aplicada no controle difuso. No controle concentrado a própria decisão do Supremo acerca da questão da constitucionalidade já afasta a aplicação da norma nos demais casos.

Uma parte significativa da doutrina questiona a permanência dessa atribuição do Senado diante da realidade do controle de constitucionalidade nos dias de hoje. Para o professor Luís Roberto Barroso, "respeitada a razão histórica da previsão constitucional, quando da sua constituição em 1934, já não mais há lógica razoável em sua manutenção". 58 No mesmo sentido, observa o professor Fábio Leite:

\begin{abstract}
Compreende-se que o receio de se atribuir um poder excessivo ao Judiciário tenha motivado o constituinte de 1934 a criar e o de 1946 a manter tal atribuição àquela casa de representação federativa, assegurando assim a possibilidade de se conferir eficácia erga omnes à declaração de inconstitucionalidade proferida pelo STF, sem o "risco" de se estar conferindo tamanho poder ao Judiciário. No entanto, a partir do momento em que se criou a fiscalização abstrata, tal justificativa perdeu a razão de ser. ${ }^{59}$
\end{abstract}

Alexandre de Moraes observa que, após a Emenda Constitucional nº. 45/04, o Supremo Tribunal Federal, no controle incidental de constitucionalidade, poderá editar Súmulas Vinculantes, desde que observados os requisitos do artigo 103-A da Constituição, não sendo mais necessária a intervenção do Senado para que a decisão tenha efeito contra todos. ${ }^{60}$

Gilmar Ferreira Mendes, no entanto, vai além e propõe a seguinte releitura do dispositivo:

\footnotetext{
${ }^{57}$ A doutrina diverge quanto à atribuição de efeitos, para Barroso a eficácia dessa suspensão seria ex tunc, já para Bandeira de Melo, Oswaldo Aranha, José Afonso e Themístocles Cavalcanti esses efeitos seriam ex nunc.

${ }^{58}$ BARROSO, Luís Roberto. Op. cit, p. 122.

${ }^{59}$ LEITE, Fábio Carvalho. ADIN e ADC, e a Ambivalência Possível: Uma Proposta. p. 19.

${ }^{60}$ MORAES, Alexandre de. Direito Constitucional. 21 ${ }^{a}$ ed. São Paul: Atlas, 2007, p. 690.
} 
Parece legítimo entender que a fórmula relativa a suspensão de execução da lei pelo Senado Federal há de ter simples efeito de publicidade. Dessa forma, se o Supremo Tribunal Federal, em sede de controle incidental, chegar à conclusão, de modo definitivo, de que a lei é inconstitucional, essa decisão terá efeitos gerais, fazendo-se a comunicação ao Senado Federal para que publique a decisão no Diário do Congresso. Tal como assente, não é (mais) a decisão do Senado que confere eficácia geral ao julgamento do Supremo. A própria decisão da Corte contém essa força normativa. ${ }^{61}$

O autor supracitado acredita estar diante de um processo de mutação constitucional e aponta os seguintes argumentos: 1) esse papel do Senado teria sido fortemente abalado com o alargamento do controle abstrato pela Constituição de 1988; 2) a ampliação do rol de legitimados para a propositura da ação direta de inconstitucionalidade reduziu o significado do controle difuso; 3 ) como a disciplina processual conferida à argüição de descumprimento de preceito fundamental é utilizada também nos casos não contemplados pelo controle concentrado, uma decisão de caso concreto em ADPF seria dotada de eficácia erga omnes, ao passo que a mesma questão decidida no controle incidental teria os efeitos limitados às partes, o que seria uma incoerência; 4) o artigo 557, caput, do Código de Processo Civil, autoriza o relator a negar provimento a recurso quando contrariar súmula ou jurisprudência dominante do respectivo tribunal, do Supremo Tribunal Federal ou de Tribunal Superior, o que já traduz um efeito vinculante das decisões do Supremo; 5) o artigo 557, $\S 1^{\circ}$ - A do Código de Processo Civil que autoriza o relator a dar provimento ao recurso se a decisão recorrida estiver em manifesto confronto com súmula ou jurisprudência dominante do Supremo Tribunal Federal ou de Tribunal Superior, outro artigo que mostra a força vinculante das decisões do Supremo; 6) o fato de as decisões de inconstitucionalidade em ações coletivas não possuem eficácia inter partes; 7) a possibilidade de o STF editar súmula vinculante, que acaba por dotar a declaração de inconstitucionalidade proferida em sede incidental de efeitos vinculantes; 8) aponta ainda que a retirada do ordenamento jurídico da

\footnotetext{
${ }^{61}$ MENDES, Gilmar Ferreira; COELHO, Inocêncio Mártire; BRANCO, Paulo Gustavo Gonet. Op. cit, p. 1090.
} 
norma inconstitucional não seria a medida mais adequada para as atuais decisões do Supremo Tribunal Federal, já que este tribunal, no julgamento a respeito da constitucionalidade, não mais se restringe a declarar ou não a inconstitucionalidade da norma: muitas vezes fixa uma orientação constitucionalmente adequada, adota uma interpretação conforme (indica a interpretação compatível com a Constituição, determinando ainda um complemento ou uma restrição), ou declara a inconstitucionalidade parcial sem redução do texto, e para esses tipos de decisão não seria coerente falar em suspensão da execução da lei pelo Senado Federal; entre outros $\operatorname{argumentos}^{62}$.

A discussão a respeito dessa possível mutação constitucional apontada pelo ministro Gilmar Mendes é o tema central desse trabalho e será exposta no capítulo seguinte.

Apesar de criticado por alguns doutrinadores, o dispositivo constitucional é claro e continua em vigor.

\footnotetext{
${ }^{62}$ MENDES, Gilmar Ferreira; COELHO, Inocêncio Mártire; BRANCO, Paulo Gustavo Gonet. Op. cit, p. 1082-91.
} 


\section{CAPÍTULO 3}

\section{RECLAMAÇÃO №. 4335 E A SUPOSTA MUTAÇÃO CONSTITUCIONAL}

\subsection{Jurisdição Constitucional e Limites da Interpretação Constitucional}

O constitucionalismo, que surgiu como uma forma de limitação do poder dos governantes, sofreu mudanças paradigmáticas diante do atual Estado Democrático de Direito. Nesse contexto, o Novo Constitucionalismo caracteriza-se por: a) mais Constituição do que leis, a Constituição que antes era considerada fonte de direito mediata, atualmente é a norma suprema e o fundamento de validade de todas as demais normas; b) mais juízes do que legisladores, com o reconhecimento de que os juízes são os verdadeiros criadores do direito no caso concreto, e não apenas revelam a vontade do legislador; c) mais princípios do que regras, devido à inserção nas constituições de preceitos abertos, que comportam múltiplas interpretações; d) mais ponderação do que subsunção, a tradicional regra de subsunção não se mostra eficiente nos novos conflitos hermenêuticos trazidos pelo novo constitucionalismo, principalmente no que toca à aplicação dos princípios constitucionais; e d) mais concretização do que interpretação, pois que, à luz dos casos concretos, o operador do direito escolhe uma entre as múltiplas acepções dos princípios constitucionais. ${ }^{63}$

Jurisdição constitucional refere-se à atividade dos juízes de interpretar e aplicar a Constituição. Não se trata apenas de questões que envolvam o controle de constitucionalidade de leis e atos normativos, mas, também, daquelas em que a Constituição seja aplicada diretamente para a solução de litígios. Na definição de Luís Roberto Barroso:

Jurisdição Constitucional designa a aplicação da Constituição por juízes e tribunais. Essa aplicação poderá ser direta, quando a norma constitucional

\footnotetext{
${ }^{63}$ MENDES, Gilmar Ferreira; COELHO, Inocêncio Mártire; BRANCO, Paulo Gustavo Gonet. Op. cit., p.126-9.
} 
discipline, ela própria, determinada situação da vida. Ou indireta, quando a Constituição sirva de referência para a atribuição de sentido a uma norma infraconstitucional ou de parâmetro de sua validade. Neste último caso estar-se-á diante do controle de constitucionalidade, que é, portanto, uma das formas de exercício da jurisdição constitucional. ${ }^{64}$

A indicação do Estado Democrático de Direito como o paradigma do Novo Constitucionalismo implica uma tensão entre jurisdição e legislação, pois que "as normas constitucionais não podem ser interpretadas sem o recurso a valorações políticas: tais valorações, porém, são sempre, até em determinado ponto, subjetivas",65. Nesse cenário, decisões políticas importantes cada vez mais se deslocam do âmbito dos Poderes Legislativo e Executivo, caminhado para o âmbito do Poder Judiciário, o que para muitos significa o início de um "governo dos juízes". Nesse sentido, o verdadeiro legislador:

É aquele que dispõe de autoridade absoluta para interpretar quaisquer normas jurídicas, escritas ou faladas, e não a pessoa que por primeiro as escreveu ou transmitiu verbalmente, uma assertiva de resto semelhante à que formularam Hobbes e Perelmann, sempre lembrados, no sentido de que o legislador [atual] não é aquele por cuja vontade se editaram as leis, mas aquele que, podendo revogá-las ou interpretá-las autenticamente, as mantém em vigor com o sentido em que vêm sendo aplicadas. ${ }^{66}$

Toda essa onipotência judicial faz surgir a discussão a respeito da legitimidade democrática da jurisdição constitucional, na medida em que decisões de um Poder não eleito pelo povo se sobrepõem a decisões de órgãos representativos da vontade popular. De acordo com Alexandre de Moraes, "a jurisdição constitucional retira sua legitimidade formalmente da própria Constituição e materialmente da necessidade de proteção ao Estado de Direito e aos Direitos Fundamentais" ${ }^{67}$. No tocante ao tema, Gustavo Binenbojm observa que:

\footnotetext{
${ }^{64}$ BARROSO, Luís Roberto. Op. cit. p. 3.

${ }^{65}$ BACHOF, Otto. Estado de Direito e Poder Político. Boletim da Faculdade de Direito de Coimbra, vol. LVI. Coimbra, Coimbra Editora, 1996, p. 10. Apud STRECK, Lenio Luiz. Jurisdição Constitucional e Hermenêutica: uma nova crítica do direito. $2^{\mathrm{a}}$. ed. - Rio de Janeiro: Forense, 2004, p. 106.

${ }^{66}$ MENDES, Gilmar Ferreira; COELHO, Inocêncio Mártire; BRANCO, Paulo Gustavo Gonet. Op. cit., p.134.

${ }^{67}$ MORAES, Alexandre de. Jurisdição Constitucional e Tribunais Constitucionais: garantia suprema da Constituição. 2a . ed. São Paulo: Atlas, 2003, p. 313.
} 
A supremacia da Constituição e a jurisdição constitucional são mecanismos pelos quais determinados princípios e direitos, considerados inalienáveis pelo poder constituinte originário, são subtraídos da esfera decisória ordinária dos agentes políticos eleitos pelo povo, ficando protegidos pelos instrumentos de controle de constitucionalidade das leis e atos do Poder Público. A jurisdição constitucional é, portanto, uma instância de poder contramajoritário, no sentido de que sua função é mesmo a de anular determinador atos votados e aprovados, majoritariamente, por representantes eleitos. Nada obstante, entende-se, hodiernamente, que os princípios e direitos fundamentais, constitucionalmente assegurados, são, em verdade, condições estruturantes e essenciais ao bom funcionamento do próprio regime democrático; assim, quando a justiça constitucional anula leis ofensivas a tais princípios ou direitos, sua intervenção se dá a favor, e não contra a democracia. Essa é a fonte maior de legitimidade da jurisdição constitucional. ${ }^{68}$

Diante do Novo Constitucionalismo, compete ao intérprete construir a norma adequada para a solução do caso concreto. Todavia, essa atividade não é totalmente livre. Nesse contexto, faz-se necessária a análise do processo hermenêutico, em especial no que tange aos limites da interpretação constitucional.

A interpretação constitucional parte de um texto, sendo ele um importante limite à atividade hermenêutica. $\mathrm{O}$ próprio texto constitucional funciona como uma barreira para os excessos de interpretação. Assim, quanto mais preciso for o enunciado, menor será o espaço de discricionariedade judicial, minimizando as possibilidades de interpretações válidas. Por outro lado, quanto menos preciso o texto, maiores serão as chances de múltiplas interpretações.

Outro limite à interpretação constitucional é o espírito da Constituição, ou seja, a interpretação de um dispositivo, além de não poder ser contrária ao seu próprio texto, também deve observar os demais preceitos constitucionais. Isso decorre do princípio de unidade da Constituição. Nesse sentido, Inocêncio Coelho observa que:

Muito embora não se deva entender a Constituição como um texto estático e rígido, completamente indiferente às alterações da realidade constitucional, isso não significa entregar o seu texto à discrição dos intérpretes/aplicadores,

\footnotetext{
${ }^{68}$ BINENBOJM, Gustavo. A Nova Jurisdição Constitucional Brasileira: legitimidade democrática e instrumento de realização. Rio de Janeiro: Renovar, 2001, p. 224.
} 
liberando-o para leituras que, realizadas à margem ou além da fala constitucional, acarretem alterações não permitidas pela Constituição. ${ }^{69}$

Assim, de acordo com Lenio Streck, "o papel da jurisdição é o de levar adiante a tarefa de construir interpretativamente, com a participação da sociedade, o sentido normativo da Constituição e do projeto de sociedade democrática a ela subjacente" ${ }^{70}$. O autor destaca ainda que a jurisdição constitucional não pode ser entendida como uma substituição do poder constituinte pelo Poder Judiciário, idéia que violaria a própria noção de democracia. "Um tribunal não pode paradoxalmente subverter a Constituição sob o argumento de a estar garantindo ou guardando" ${ }^{71}$.

\subsection{Análise da Reclamação n‥ 4335/AC}

A Reclamação nº. 4335/AC foi ajuizada, no Supremo Tribunal Federal, pela Defensoria Pública do Estado de Acre em face de decisão do Juiz de Direito da Vara de Execuções Penais da Comarca de Rio Branco, do Estado do Acre, que havia indeferido o pedido de progressão de regime em favor de onze réus.

No julgamento do Habeas Corpus 82.959, o STF havia reconhecido, incidentalmente, a inconstitucionalidade do artigo $2^{\circ}, \S 1^{\circ}$, da Lei 8.072/1990 ${ }^{72}$, em função do princípio constitucional da individualização da pena e, portanto, afastou a vedação da progressão de regime nos crimes hediondos. Com base nesse julgado anterior, a Reclamante inicialmente solicitou a concessão de progressão de regime para os referidos réus perante o Juízo da Vara de Execuções Penais da Comarca de Rio Branco, que

\footnotetext{
${ }^{69}$ MENDES, Gilmar Ferreira; COELHO, Inocêncio Mártire; BRANCO, Paulo Gustavo Gonet. Op. cit., p.132.

${ }^{70}$ STRECK, Lenio Luiz; OLIVEIRA, Marcelo Andrade Cattoni de. A nova perspectiva do Supremo Tribunal Federal sobre o controle difuso: mutação constitucional e limites da legitimidade da jurisdição constitucional.

${ }^{71}$ Ibid.

${ }^{72} \mathrm{O}$ artigo $2^{\circ}$ da Lei 8.072/1990 trata dos crimes hediondos, da prática da tortura, do tráfico ilícito de entorpecentes e drogas afins e do terrorismo. Seu parágrafo primeiro estabelecia que "a pena cumprida por crimes previstos nesse artigo será cumprida integralmente em regime fechado". Destaca-se que, atualmente, a redação do dispositivo em questão já foi alterada pela Lei 11.464/2007, que passou a ter a seguinte redação: “a pena por crime previsto neste artigo será cumprida inicialmente em regime fechado".
} 
indeferiu o pedido, alegando a vedação legal em admitir a progressão de regime e argumentou da seguinte forma:

“(...) conquanto o Plenário do Supremo Tribunal Federal, em maioria apertada (6 votos x 5 votos), tenha declarado 'incidenter tantum' a inconstitucionalidade do artigo $2^{\circ}$, $\S 10$, da Lei 8072/90 (Crimes Hediondos), por via do Habeas Corpus n. 82.959, isto após dezesseis anos dizendo que a norma era constitucional, perfilhome a melhor doutrina constitucional pátria que entende que no controle difuso de constitucionalidade a decisão produz efeitos 'inter partes'. (fl. 23-24)", 73

A Reclamante alegou que, por conta dessa decisão, os condenados encontravam-se cumprindo pena em regime integralmente fechado pela prática de crime hediondo. Em virtude disso ajuizou a referida Reclamação, perante o Supremo Tribunal Federal, apontando ofensa à autoridade das decisões do STF em função do descumprimento da decisão daquele Tribunal no HC 82.959 pelo Juízo da Vara de Execuções Penais da Comarca de Rio Branco.

Destaca-se que o aspecto penal da Reclamação é incontroverso. Nos quatro votos já proferidos, a vedação da progressão de regime foi considerada inconstitucional e afastada, competindo ao juiz examinar os demais requisitos para o deferimento da progressão. Os ministros Gilmar Mendes e Eros Grau julgaram procedente a Reclamação. O Ministro Sepúlveda Pertence julgou improcedente a Reclamação, mas concedeu habeas corpus de ofício. Já o Ministro Joaquim Barbosa não conheceu a Reclamação, mas também concedeu habeas corpus de ofício. Soma-se a isso, o fato de a Lei 11.464/2007 ter alterado a redação do mencionado dispositivo, permitindo a progressão de regime nos casos de crimes hediondos e equiparados.

A grande questão discutida nessa Reclamação envolve os efeitos da decisão do Supremo Tribunal Federal no controle difuso de constitucionalidade.

\footnotetext{
73 Trecho do voto do Juiz da vara de Execuções Penais da Comarca de Rio Branco/ AC, retirado do relatório da Reclamação no. 4335/AC, elaborado pelo Ministro Gilmar Mendes, p. 2.
} 
Como observado no capítulo anterior, o Brasil adota o sistema híbrido de controle de constitucionalidade, combinando o controle concentrado/abstrato com o controle difuso/concreto. Dessa forma, qualquer juiz ou tribunal, em um caso concreto, poderá deixar de aplicar uma lei por considerá-la inconstitucional e essa decisão terá efeitos inter partes, ainda que seja proferida pelo STF. Essa decisão somente poderá atingir eficácia erga omnes se o Senado Federal, na sua competência privativa conferida pelo artigo 52, X, da Constituição Federal, suspender, no todo ou em parte, a norma declarada inconstitucional por decisão definitiva do Supremo Tribunal Federal. Por outro lado, no controle concentrado/abstrato a questão da inconstitucionalidade será analisada como o objeto principal da ação a ser julgada pelo $\operatorname{STF}^{74}$ e a decisão terá eficácia contra todos e efeito vinculante aos demais órgãos do Poder Judiciário e à Administração Pública, sem que seja necessária a atuação do Senado Federal.

No entanto, na Reclamação aqui analisada, o Ministro relator Gilmar Mendes, em seu voto, defendeu a eficácia vinculante também das decisões do STF proferidas em sede de controle difuso, alegando a ocorrência de uma autêntica mutação constitucional com relação ao artigo 52 , X, da Constituição, pela qual o atual papel do Senado Federal no controle de constitucionalidade se resumiria a mero publicador das decisões definitivas do STF em controle difuso, que já teriam, por si só, força vinculante. Essa posição foi acompanhada pelo Ministro Eros Grau. Contrários a esse entendimento, posicionaram-se os ministros Sepúlveda Pertence e Joaquim Barbosa. O julgamento da Reclamação encontra-se suspenso em razão do pedido de vista do Ministro Ricardo Lewandowski.

\footnotetext{
74 Destaca-se que no controle de constitucionalidade concentrado/abstrato, que tem como parâmetro a Constituição Estadual, o órgão competente para o conhecimento da ação direta será o Tribunal de Justiça do Estado ou do Distrito Federal.
} 


\subsubsection{Análise dos Votos}

O Ministro Relator Gilmar Mendes julgou procedente a Reclamação $\mathrm{n}^{\circ}$. 4335 por entender que no caso havia desrespeito à autoridade de decisão anterior do Supremo Tribunal Federal, ou seja, para o Exm $^{\circ}$. Ministro, a decisão proferida no referido habeas corpus, ainda que em sede de controle de constitucionalidade difuso, teria sim efeito vinculante e a sua não observância ensejaria a utilização da reclamação constitucional.

Nesse sentido, o Ministro Gilmar Mendes propõe uma releitura do papel do Senado Federal no controle difuso de constitucionalidade. O entendimento prevalente no STF de que o ato político do Senado emprestava eficácia genérica à decisão definitiva, dando alcance normativo ao julgado do Supremo Tribunal Federal, de acordo com o Exm ${ }^{\circ}$. Ministro, está em descompasso com a realidade constitucional.

Argumenta o Ministro que a única plausibilidade do instituto no nosso ordenamento jurídico atual é a sua importância histórica. Acrescenta que essa competência privativa do Senado estaria restrita aos casos de declaração de inconstitucionalidade da lei ou ato normativo, não se mostrando eficaz nos casos em que o STF adota uma interpretação conforme a Constituição, ou declara uma inconstitucionalidade parcial sem redução do texto, ou que declara a não-recepção da lei pré-constitucional, entre outros casos.

Aponta também a questão da repercussão da declaração de inconstitucionalidade proferida pelo Supremo Tribunal Federal sobre as decisões de outros tribunais. Um exemplo é o entendimento jurisprudencial do STF, positivado pela Lei 9.756/1998 no artigo 481, parágrafo único, do Código de Processo Civil, a respeito do princípio constitucional da reserva de plenário. Assim, quando o Plenário do STF decide a respeito da inconstitucionalidade de uma norma, dispensa-se que o assunto seja discutido no pleno ou órgão especial de outros tribunais. De acordo com o Ministro Relator, essa decisão antecipa o efeito vinculante dos julgados do STF em matéria de controle de constitucionalidade incidental, sendo um 
dos passos da equiparação dos efeitos das decisões proferidas em controle abstrato e concreto.

No voto são apontadas outras modificações importantes introduzidas no Código de Processo Civil, como a negativa de seguimento a recurso quando contrariar súmula do Supremo Tribunal Federal ou do Superior Tribunal de Justiça (artigo 557, caput) e, também, a possibilidade do relator, monocraticamente, dar seguimento ao recurso quando a decisão recorrida estiver em manifesto confronto com súmula ou jurisprudência dominante do respectivo tribunal, do Supremo Tribunal Federal ou Superior Tribunal de Justiça (artigo 557, $\left.\S 1^{\circ}-\mathrm{A}\right)$ - decisões essas que demonstram efeito vinculante das decisões do STF.

Outra questão apontada pelo Ministro Relator refere-se ao fato de a Constituição de 1988 ter priorizado o controle concentrado/abstrato de constitucionalidade, em razão do alargamento do rol dos legitimados para a propositura das ações diretas e a criação da ação direta de constitucionalidade e da argüição de descumprimento de preceito fundamental.

Destaca o Ministro ser inútil a suspensão pelo Senado Federal de lei declarada inconstitucional em sede de ação civil pública ou mandado de segurança coletivo, pois que, pela natureza coletiva da ação, os efeitos transcendem as partes litigantes.

Em suma, o Ministro Gilmar Mendes sustenta ser necessária uma releitura dos institutos vinculados ao controle incidental de constitucionalidade, especialmente a exigência de maioria absoluta para a declaração de inconstitucionalidade e a suspensão da execução de lei pelo Senado Federal. Com fundamento em todos os argumentos apresentados, o Ministro afirma estarmos diante de uma autêntica mutação constitucional e conclui o seu voto da seguinte forma:

Assim, parece legítimo entender, hodiernamente, a fórmula relativa à suspensão de execução da lei pelo Senado Federal há de ter simples efeito de publicidade. Desta forma, se o Supremo Tribunal Federal, em sede de controle incidental, 
chegar à conclusão, de modo definitivo, de que a lei é inconstitucional, essa decisão terá efeitos gerais, fazendo-se a comunicação ao Senado Federal para que este publique a decisão no Diário do Congresso. Tal como assente, não é (mais) a decisão do Senado que confere eficácia geral ao julgamento do Supremo. A própria decisão da Corte contém essa força normativa. Parece evidente ser essa a orientação implícita nas decisões judiciais e legislativas acima referidas. Assim, o Senado não terá a faculdade de publicar ou não a decisão, uma vez que não se cuida de uma decisão substantiva, mas de simples dever de publicação, tal como reconhecido a outros órgãos políticos em alguns sistemas constitucionais. ${ }^{75}$

No mesmo sentido, posicionou-se o Ministro Eros Grau, que, em seu voto, defendeu a ocorrência da mutação constitucional com relação ao dispositivo 52, inciso X, da Constituição Federal. De acordo com o Ministro:

\begin{abstract}
A mutação constitucional é transformação de sentido do enunciado da Constituição sem que o próprio texto seja alterado em sua redação, vale dizer, na sua dimensão constitucional textual. Quando ela se dá, o intérprete extrai do texto norma diversa daquelas que nele se encontravam originariamente involucradas, em estado de potência. Há, então, mais do que interpretação, esta concebida como processo que opera transformação de texto em norma. Na mutação constitucional caminhamos não de um texto a uma norma, porém de um texto a outro texto, que substitui o primeiro. [...] O exemplo que se colhe no caso é extremamente rico. Aqui passamos em verdade de um texto [compete privativamente ao Senado Federal suspender a execução, no todo ou em parte, de lei declarada inconstitucional por decisão definitiva do Supremo Tribunal Federal] a outro texto [compete privativamente ao Senado Federal dar publicidade à suspensão da execução, operada pelo Supremo Tribunal Federal, de lei declarada inconstitucional, no todo ou em parte, por decisão definitiva do Supremo]. ${ }^{76}$
\end{abstract}

Assim, defende o Ministro Eros Grau que o Ministro Relator não se excedeu ao intitular de mutação constitucional a mudança de entendimento a respeito do papel do Senado Federal no controle difuso de constitucionalidade.

Em outro sentido, o Ministro Sepúlveda Pertence não concorda com a realização da referida mutação constitucional. Concorda com um certo efeito vinculante das decisões do Supremo, como a que dispensa a observância da reserva de plenário por outros tribunais quando o Supremo Tribunal já houver se manifestado pela declaração da inconstitucionalidade da norma, mas aponta que isso não é suficiente para reduzir o papel do Senado Federal, contemplado nas nossas constituições desde 1934. Dessa

\footnotetext{
${ }^{75}$ Recl no. 4335/AC, voto do Ministro Relator Gilmar Mendes, p. 54-5.
} 
forma, para o $\mathrm{Exm}^{\circ}$. Ministro, é evidente a convivência paralela entre os sistemas de controle concentrado/abstrato e difuso/concreto, e que este último depende da atuação do Senado para obter eficácia erga omnes e vinculante.

E, por fim, em razão da prioridade que a Constituição de 1988 conferiu ao controle concentrado/abstrato, também concorda que o papel do Senado Federal no controle de constitucionalidade difuso vem se tornando cada vez mais obsoleto. Ainda assim, o Ministro não acredita ser o caso de uma autêntica mutação constitucional. De acordo com Sepúlveda Pertence, o STF poderá conferir eficácia erga omnes e vinculante as suas decisões obedecendo ao procedimento previsto para a edição de súmulas vinculantes, sem, portanto, reduzir o Senado a um órgão de publicidade de suas decisões.

O Ministro Joaquim Barbosa, na mesma linha do voto do Ministro Sepúlveda Pertence, destacou que não seria necessária a mudança no sistema de controle de constitucionalidade para que as decisões do STF adquiram ampla efetividade; basta que o Supremo Tribunal Federal edite uma súmula vinculante. Dessa forma, seria mantida a leitura tradicional do artigo 52, X, da Constituição Federal, que se refere a uma autorização ao Senado para suspender a execução de dispositivo declarado inconstitucional por decisão definitiva do STF.

O Ministro também rejeitou a proposta de mutação constitucional, sob o argumento de que seriam necessários dois fatores adicionais para a ocorrência do mencionado fenômeno, a saber, o decurso de um espaço de tempo maior para verificar a mutação constitucional e o conseqüente e definitivo desuso do dispositivo. Concluindo, destacou que a referida proposta não seria permitida em razão de violar a literalidade do artigo 52, $\mathrm{X}$, da Constituição, além de ser contrária às regras de auto-restrição.

Com a análise desses quatro votos já proferidos, é clara a cisão do Supremo Tribunal Federal em duas teses. Uma defendida pelos ministros

\footnotetext{
${ }^{76} \operatorname{Recl} n^{\circ} .4335 / A C$, voto do Ministro Eros Grau, p. 9-10.
} 
Gilmar Mendes e Eros Grau, sustentando a realização de uma mutação constitucional que reduziria o papel do Senado Federal no controle de constitucionalidade difuso a mero publicador de decisões definitivas proferidas pelo STF, uma vez que as decisões, por si só, já seriam dotadas de efeito vinculante. De outro lado, a tese dos Ministros Sepúlveda Pertence e Joaquim Barbosa, que defendem a permanência do sistema de controle de constitucionalidade híbrido no país e, sem reduzir o Senado Federal a órgão de publicação das decisões do STF, apontam, como meio eficaz para conferir eficácia vinculante às decisões do Supremo Tribunal Federal, a edição de súmulas vinculantes.

\subsubsection{A Suposta Mutação (In)Constitucional}

Esse julgamento pode resultar, caso sejam majoritários os votos proferidos pelos ministros Gilmar Mendes e Eros Grau, em uma nova concepção, não apenas a respeito do controle de constitucionalidade no país, mas também a respeito da teoria do poder constituinte, do equilíbrio entre os Poderes e do pacto-federativo. Isso porque, de acordo com o Direito Constitucional consolidado no país, uma modificação constitucional que confira eficácia erga omnes e efeito vinculante às decisões proferidas pelo STF, em sede de controle de constitucionalidade difuso, só poderia ser realizada por meio do poder constituinte derivado, através de reforma constitucional, ou ainda, por meio do poder constituinte originário com a criação de uma nova Constituição.

Entretanto, nos mencionados votos dos ministros Gilmar Mendes e Eros Grau, a suposta mudança a respeito dos efeitos das decisões proferidas em controle difuso de constitucionalidade se dá por meio de uma nova "interpretação" do artigo 52, X, da Constituição Federal - fenômeno que os ministros intitularam de mutação constitucional.

Todavia, essa mudança de entendimento ultrapassa os limites da interpretação constitucional revelando uma verdadeira mutação inconstitucional, uma vez que retira toda a função constitucional do Senado 
Federal no controle difuso de constitucionalidade, reduzindo a mero publicador das decisões definitivas do Supremo Tribunal Federal - o que significa verdadeira ingerência, não autorizada pela Constituição, do Poder Judiciário no Poder Legislativo. Destaca-se que para garantir a mencionada publicidade já existe o Diário Oficial.

Como dito no item anterior, a interpretação constitucional é limitada pelo próprio texto normativo, e assim, quanto mais preciso o texto, menor será a atividade interpretativa. Dessa forma, a referida mutação constitucional é ilegítima, pois ultrapassa os limites no que toca à interpretação do texto constitucional, uma vez que o artigo 52, X, da Constituição, é um dispositivo objetivo e claro, o que reduz as possibilidades de interpretações válidas. Soma-se a isso o fato da mesma Constituição de 1988 que priorizou o controle concentrado, ter mantida viva a competência do Senado para suspender a execução da lei declarada inconstitucional.

Todos os argumentos apresentados em favor da ocorrência da mutação constitucional, seja a prioridade dada pela Constituição ao controle concentrado/abstrato, seja a questão da economia processual, ou a constatação de certas decisões que já vinculam os demais membros do Poder Judiciário, não legitimam a realização de uma mutação inconstitucional. Nesse sentido:

Isso não legitima ignorar um comando constitucional ainda vigente, enxertandolhe um sentido que ele não comporta. [...] o texto constitucional impõe uma barreira que não pode ser simplesmente transposta, ou ignorada, sob o argumento de se querer "adequar" o controle difuso ao (prevalente) controle concentrado, nem sob a alegação de se pretender desafogar a pauta de processos da corte. ${ }^{77}$

\subsection{Abstrativização do Controle Difuso}

Inicialmente, faz-se necessário destacar que a expressão "abstrativização do controle difuso" foi utilizada por Fredie Didier, na análise das mudanças 
ocorridas com o recurso extraordinário, referindo-se à tese de que as decisões do Supremo Tribunal Federal, em sede de controle incidental de constitucionalidade, seriam, por si só, dotadas de eficácia erga omnes e efeito vinculante, sem a necessidade de suspensão da execução da lei ou ato normativo pelo Senado Federal. ${ }^{78}$

Essa mudança paradigmática no sistema de controle de constitucionalidade brasileiro foi defendida pelos Ministros Gilmar Mendes e Eros Grau na Reclamação no . 4335/AC, conforme já exposto.

A favor da tese da abstrativização, defende-se a impossibilidade do Supremo Tribunal Federal acumular as funções de Tribunal Constitucional e Tribunal Recursal, devendo aquela função prevalecer em detrimento desta. Esse entendimento seria uma decorrência lógica do próprio caput do artigo 102 da Constituição, que estabelece competir ao STF a guarda precípua da Constituição.

Salienta-se que essa dupla função do Supremo Tribunal Federal gera a multiplicação e engessamento da Corte com demandas envolvendo questões particulares. Nessa linha, são apontadas algumas inovações legislativas que reduzem o número de demandas ao STF, a saber, a necessidade de repercussão geral e pré-questionamento nos recursos extraordinários, a possibilidade de edição de súmulas vinculantes e a técnica de modulação dos efeitos da decisão prevista para o controle concentrado, que também vem sendo utilizada pelo STF em sede de controle difuso. Soma-se a isso a já mencionada preferência que a Constituição atribui ao controle concentrado/abstrato quando cria novas ações diretas no controle de constitucionalidade e amplia o rol de legitimados para a sua propositura.

\footnotetext{
${ }^{77}$ LEITE, Glauco Salomão. A extensão da eficácia erga omnes e do efeito vinculante às decisões de inconstitucionalidade em controle difuso pelo Supremo Tribunal Federal: hipótese de mutação (in)constitucional, p. 14-5.

${ }^{78}$ DIDIER JR., Fredie. Transformações do Recurso Extraordinário. In: Processo e Constituição. Estudos em homenagem a professor José Carlos Barbosa Moreira. Luiz Fux, Nelson Nery Júnior, Teresa Arruda Alvim Wambier (coordenadores). São Paulo: RT, 2006, p. 104 - 21. Apud MONTEZ, Marcus Vinícius Lopes. A abstrativização do controle difuso.
} 
Nesse sentido, Gilmar Mendes, em seu voto, no Recurso Extraordinário $\mathrm{n}^{\circ}$. 376.852, alegou que o recurso extraordinário "deixa de ter caráter marcadamente subjetivo ou de defesa de interesse das partes, para assumir, de forma decisiva, a função de defesa da ordem constitucional objetiva"79

Entretanto, boa parte da doutrina demonstra forte resistência em aceitar a tese da abstrativização do controle concentrado. Glauco Salomão Leite ressalta o fato de que, apesar da Constituição de 1988 ter priorizado o controle concentrado/abstrato, ela manteve intacta a competência do Senado Federal de suspender a execução de lei ou ato normativo declarado inconstitucional pelo STF. Tratou-se, pois, de uma opção do poder constituinte originário em manter o sistema de controle de constitucionalidade híbrido no país, com a participação do Senado no controle difuso. Nesse sentido:

Portanto, é preciso reconhecer que, apesar de todo o fortalecimento do controle concentrado com a Constituição de 1988, esta manteve incólume a competência do Senado para suspender a execução de lei declarada inconstitucional pelo STF na via difusa, o que expressa o reconhecimento de que as decisões dessa Corte, nesse tipo de controle, não anulam a lei inconstitucional, pois seus efeitos são apenas inter partes. No fundo, trata-se de aplicar o direito constitucional positivo tal como ele é, e não como deveria ser a partir da ótica de cada intérprete. ${ }^{80}$

A abstrativização do controle difuso, se acolhida, acabaria desconfigurando a idéia básica do controle incidental de constitucionalidade, a saber, a análise da constitucionalidade da norma levando em consideração os elementos específicos do caso concreto. A decisão no controle difuso/concreto não gera uma nova tese jurídica, mas sim a solução adequada para aquele caso específico. É por conta dessas peculiaridades de cada caso que a decisão apenas tem o condão de produzir efeitos entre as partes litigantes.

Essa abstrativização, no plano político, conduziria à centralização das decisões a respeito da constitucionalidade das leis no Supremo Tribunal

\footnotetext{
${ }^{79}$ STF, RE no. 376.852/SC, Rel. Min. Gilmar Mendes, DJ 13/06/2003.
} 
Federal, retirando dos tribunais inferiores e dos juízes a possibilidade de decidir, a respeito da aplicação ou não da norma, levando em conta as miudezas dos casos concretos. No plano hermenêutico, a tese em questão conduziria à petrificação dos sentidos jurídicos em detrimento das singularidades de cada caso. ${ }^{81}$

Outra questão relevante refere-se a legitimidade representativa nos modelos de controle de constitucionalidade. No controle concentrado/abstrato, a ampliação do rol dos legitimados para a propositura das ações diretas faz com que representantes da sociedade civil possam participar do processo. Dessa forma, a decisão com eficácia erga omnes e efeitos vinculantes é legitimada não apenas porque emanou da Corte Constitucional, mas, principalmente, porque a sociedade estava representada no processo. Por outro lado, no controle difuso/concreto, a decisão somente produz efeitos entre as partes porque não há uma representação da sociedade como um todo, e cada pólo da relação defende seus interesses particulares. Nesses casos, somente o Senado Federal poderá conferir eficácia erga omnes e efeitos vinculantes à decisão que declara a inconstitucionalidade de lei ou ato normativo. Isso porque o Senado é o órgão representativo dos Estados da Federação, o que confere participação democrática ao modelo difuso. Eis ai uma importante função do Senado que não pode ser descartada. ${ }^{82}$

Lenio Streck também aponta que:

Atribuir eficácia erga omnes e efeito vinculante às decisões do STF em sede de controle difuso de constitucionalidade é ferir os princípios constitucionais do devido processo legal, da ampla defesa e do contraditório (art. $5^{\circ}$, LIV e LV, da Constituição da República), pois assim se pretende atingir aqueles que não tiveram garantido o seu direito constitucional de participação nos processos de tomada da decisão que os afetará. [...] Eis, portanto, um problema central: a lesão a direitos fundamentais. ${ }^{83}$

\footnotetext{
${ }^{80}$ LEITE, Glauco Salomão. Op. cit., p. 13.

${ }^{81}$ STRECK, Lenio Luiz. Jurisdição Constitucional e Hermenêutica: uma nova crítica do direito. $2^{\mathrm{a}}$. ed. - Rio de Janeiro: Forense, 2004. p. 851.

${ }^{82}$ STRECK, Lenio Luiz; OLIVEIRA, Marcelo Andrade Cattoni de. A nova perspectiva do Supremo Tribunal Federal sobre o controle difuso: mutação constitucional e limites da legitimidade da jurisdição constitucional.

${ }^{83}$ Ibid.
} 
Quanto ao argumento utilizado pelos defensores da abstrativização com relação a uma necessária redução do número de processos dirigidos ao STF, Lenio Streck defende que não se pode priorizar uma instrumentalidade quantitativa em detrimento de uma instrumentalidade qualitativa. Assim, "trocar a democracia e a independência dos juízes pelo desafogo dos processos - tese que já ganhou corpo e sustentação no imaginário dos juristas - é preço exageradamente alto a ser pago pela sociedade" ${ }^{\Perp 4}$.

Diante de toda essa problemática, Lenio Streck aponta algumas soluções para o desafogo do Poder Judiciário, tais como uma filtragem mais eficaz dos processos, desde a origem, por meio da análise minuciosa dos requisitos da inicial, das condições da ação e dos pressupostos processuais, assim como o manejo adequado do despacho saneador. Aponta ainda que, a exemplo do que ocorre no incremento de comarcas, varas e juízes locais, também os Tribunais Superiores e o Supremo Tribunal Federal poderiam aumentar o número de ministros para melhor cumprirem o seu papel. ${ }^{85}$

\subsection{Mutação Inconstitucional e Princípio da Separação dos Poderes}

Os doutrinadores costumam apontar a origem do princípio da separação dos poderes nos escritos de Aristóteles. Entretanto, merece destaque os ensinamentos de Montesquieu, grande divulgador da clássica concepção de que "tudo estaria perdido se o mesmo homem [...] exercesse esses três poderes: o de fazer as leis, o de executar as resoluções públicas, e o de julgar os crimes ou as divergências dos indivíduos” ${ }^{\sharp 16}$. Com a Revolução Francesa, o princípio tornou-se um dogma constitucional que culminou com a previsão, na Declaração de Direitos do Homem e do Cidadão (artigo 16),

\footnotetext{
${ }^{84}$ STRECK, Lenio Luiz. Jurisdição Constitucional e Hermenêutica: uma nova crítica do direito. $2^{\mathrm{a}}$. ed. - Rio de Janeiro: Forense, 2004. p. 852.

${ }^{85}$ Ibid, p. 855-6.

${ }^{86}$ MONTESQUIEU, Charles de. Do espírito das leis. São Paulo: Difusão Européia do Livro, 1962, v. 1, p. 181. Apud MENDES, Gilmar Ferreira; COELHO, Inocêncio Mártire; BRANCO, Paulo Gustavo Gonet. Op. cit., p. 155.
} 
do princípio da separação dos poderes como pressuposto para a própria existência da Constituição.

Na definição de José Afonso da Silva, "a divisão de poderes consiste em confiar cada uma das funções governamentais (legislativa, executiva e

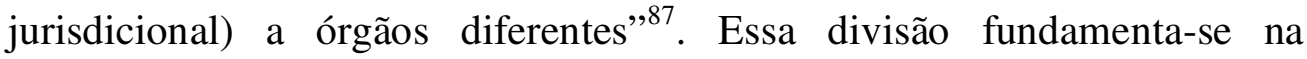
especialização funcional, sendo cada órgão especializado em uma função, e na independência orgânica, não havendo subordinação entre os órgãos.

O princípio da separação dos poderes vem sendo reconhecido pelo nosso ordenamento jurídico desde a Constituição Imperial de 1824. Na Carta Constitucional de 1988, o princípio é enunciado no artigo $2^{\circ}$ da seguinte forma: "são poderes da União, independentes e harmônicos entre si, o Legislativo, o Executivo e o Judiciário”. Essa mesma Constituição ainda o coloca como núcleo intangível, não podendo ser modificado sequer por reforma constitucional (artigo 60, parágrafo $4^{\circ}$, inciso III, da CRFB/1988).

A independência entre os Poderes significa que a investidura dos membros em cada Poder não depende da vontade ou confiança dos demais, que cada Poder é livre para agir, desde que respeite as prescrições constitucionais e legais, sendo prescindível a consulta aos demais Poderes, e que cada Poder retira a sua competência da própria Constituição, não sendo permitido que norma infraconstitucional a restrinja. A idéia de harmonia está ligada à cortesia no trato recíproco, ao respeito às prerrogativas de cada Poder e ao sistema de freios e contrapesos. ${ }^{88}$

O sistema de freios e contrapesos foi idealizado para manter a mencionada harmonia entre os Poderes. Assim, em regra, não há interferência de um Poder em outro, pois cada um possui uma esfera de atuação. No entanto, nos casos de desvios, um Poder poderá interferir no Poder desviante a fim de garantir as liberdades públicas, evitando o

\footnotetext{
${ }^{87}$ SILVA, José Afonso da. Curso de Direito Constitucional Positivo. 24a. ed. rev. e atual. São Paulo: Malheiros, 2005, p. 108.
} 
arbítrio e o autoritarismo. De acordo com Nuno Piçarra, "a prática constitucional veio, por último, revelar que o sistema de freios e contrapesos determinou, afinal, não um equilíbrio permanente entre os poderes separados, mas sim a predominância cíclica de cada um deles" ${ }^{\text {"89 }}$.

Atualmente, há uma mitigação do princípio da separação dos Poderes frente às novas exigências da sociedade moderna. Nesse contexto, é preciosa a observação de Dalmo de Abreu Dallari:

$\mathrm{Na}$ verdade, as próprias exigências de efetiva garantia de liberdade para todos e de atuação democrática do Estado requerem deste maior dinamismo e a presença constante na vida social, o que é incompatível com a tradicional separação dos poderes. É necessário que se reconheça que o dogma da rígida separação formal está superado, reorganizando-se completamente o Estado, de modo a conciliar a necessidade de eficiência com os princípios democráticos. ${ }^{90}$

Ainda sobre essa insuficiência da clássica rigidez inerente ao princípio da separação dos Poderes nos dias atuais, Inocêncio Coelho aponta que:

Esse velho dogma da sabedoria política teve de flexibilizar-se diante da necessidade imperiosa de ceder espaço para a legislação emanada do Poder Executivo, como as nossas medidas provisórias - que são editadas com força de lei - bem assim para a legislação judicial, fruto da inevitável criatividade de juízes e tribunais, sobretudo das cortes constitucionais, onde é freqüente a criação de normas de caráter geral, como as chamadas sentenças aditivas proferidas por esses supertribunais em sede de controle de constitucionalidade. ${ }^{91}$

Assim, no que se refere à moderna hermenêutica, o princípio da separação dos Poderes também necessita de uma releitura. Isso porque a interpretação judicial, sobretudo a interpretação constitucional, cada vez mais não se restringe a um ato de conhecimento, envolvendo também um ato de vontade. Dessa forma, o juiz, ao interpretar o preceito normativo, acaba por

\footnotetext{
${ }^{88}$ CASTRO, Flávia Viveiros de. O Princípio da Separação dos Poderes. In: PEXINHO, Manoel Messias; GUERRA, Isabella Franco; NASCIMENTO FILHO, Firly (Org.). Os princípios da Constituição de 1988. 2 ${ }^{\text {a }}$. ed. Rio de Janeiro: Editora Lumem Juris, 2006. p. 142.

${ }^{89}$ PIÇARRA, Nuno. A Separação dos Poderes como doutrina e princípio constitucional: um contributo para o estudo das suas origens e evolução. Coimbra: Coimbra editora, 1989, p. 184.

${ }^{90}$ DALLARI, Dalmo de Abreu. Elementos de Teoria Geral do Estado. 24 ${ }^{\text {a }}$ ed. - São Paulo: Saraiva, 2003, p. 222.

${ }^{91}$ MENDES, Gilmar Ferreira; COELHO, Inocêncio Mártire; BRANCO, Paulo Gustavo Gonet. Op. cit., p. 156.
} 
criar a norma a ser aplicável no caso concreto. Entretanto, essa atividade não é totalmente livre, tampouco discricionária, devendo respeito às normas constitucionais, às circunstâncias do caso concreto, ao dever de fundamentação e ao debate público. ${ }^{92}$

Na Reclamação $n^{\circ}$. 4335/AC, a suposta mutação constitucional proposta pelos Ministros Gilmar Mendes e Eros Grau não obedece sequer ao primeiro requisito acima apontado, uma vez que viola claramente dispositivo constitucional. Na questão, não se trata de mudança de sentido do texto constitucional, e sim de eliminação completa de uma competência constitucional atribuída ao Senado Federal, em prol de um novo "texto" constitucional que atribui uma competência ao Supremo Tribunal Federal.

Se a tese da referida mutação constitucional for majoritária, o Supremo Tribunal Federal estaria realizando uma mudança no sistema constitucional que somente seria possível mediante uma emenda constitucional pelo Poder Legislativo, desde que obedecidos os requisitos constitucionais. Nesse sentido, verifica-se uma verdadeira usurpação de competência, com o STF avocando para si uma competência que a Constituição atribuiu ao Senado Federal, o que revela flagrante violação ao princípio constitucional da separação dos Poderes.

Quanto às inovações legislativas que conferem às decisões do STF certo efeito vinculante, como a dispensa de reserva de plenário aos demais órgãos do Poder Judiciário após decisão do plenário do STF sobre a constitucionalidade, não há usurpação de poder. Não há vedação constitucional nesse sentido e o efeito vinculante somente atinge os membros do próprio Poder, não havendo ingerência de um Poder em outro. Destaca-se que não se trata de um verdadeiro efeito vinculante, uma vez que a declaração de inconstitucionalidade anterior pelo Supremo Tribunal Federa apenas dispensa os demais tribunais de submeterem a questão constitucional ao respectivo tribunal pleno ou órgão especial, quando entenderem trata-se de norma inconstitucional. Hipótese totalmente

\footnotetext{
${ }^{92}$ BARROSO, Luís Roberto. Op. cit. p. 59.
} 
diferente da discutida na Reclamação $n^{\circ}$. 4335, em que o STF (Poder Judiciário) pretende invadir a competência constitucional do Senado Federal (Poder Legislativo).

\subsection{A Questão da Súmula Vinculante}

A Emenda Constitucional n $.45 / 2004$, entre as inúmeras modificações que produziu no texto constitucional, introduziu a possibilidade do Supremo Tribunal Federal editar súmulas com efeitos vinculantes. Diferentemente das súmulas tradicionais, dotadas de função consultiva, ilustrativa da jurisprudência da Corte, a súmula vinculante passa a ter observância obrigatória para os órgãos do Poder Judiciário e da Administração Pública.

A súmula vinculante encontra assento constitucional no artigo 103A, que estabelece dois requisitos formais para a sua edição. A súmula editada pelo Supremo Tribunal Federal somente adquirirá efeito vinculante se for aprovada pelo quórum mínimo de dois terços dos seus ministros e, após reiteradas decisões sobre matéria constitucional. Dessa forma, não é qualquer decisão isolada que ensejará a edição de uma súmula vinculante, que deverá ser reflexo de reiterados julgados do Tribunal com a mesma interpretação.

A edição, cancelamento ou revisão de súmulas vinculantes é de competência do Supremo Tribunal Federal, que poderá realizar de ofício ou mediante provocação. O parágrafo segundo do artigo 103-A, da Constituição, estabelece que serão legitimados para tanto os mesmos legitimados para a propositura da ação direta de inconstitucionalidade, sem prejuízo do que vier a ser estabelecido em lei. Com essa autorização constitucional, a Lei $\mathrm{n}^{\circ}$. 11.417/2006, que regula a edição, revisão e cancelamento de súmulas vinculantes, em seu artigo $3^{\circ}$, amplia o rol de legitimados. Assim, além dos legitimados constitucionais (Presidente da República, Mesa do Senado Federal, Mesa da Câmara dos Deputados, Procurador-Geral da República, Conselho Federal da Ordem dos Advogados do Brasil, partido político com representação no Congresso 
Nacional, confederação sindical ou entidade de classe de âmbito nacional, Mesa de Assembléia Legislativa ou da Câmara Legislativa do Distrito Federal e o Governador de Estado ou do Distrito Federal), o mencionado dispositivo elenca o Defensor Público-Geral da União, os Tribunais Superiores, os Tribunais de Justiça de Estados ou do Distrito Federal, os Tribunais Regionais Federais, os Tribunais Regionais do Trabalho, os Tribunais Regionais Eleitorais e os Tribunais Militares. Destaca-se que os Municípios terão legitimidade incidental, no curso de processo em que sejam parte.

Esse amplo rol de legitimados ativos, somados à previsão do parágrafo segundo do artigo $3^{\circ}$ da Lei, que permite a manifestação de terceiros no processo, confere legitimidade democrática à edição de súmulas vinculantes.

Após a publicação na imprensa oficial, a súmula terá eficácia geral e vinculante em relação aos demais órgãos do Poder Judiciário e à Administração Pública. É importante ressaltar que a súmula vinculante não produz qualquer efeito com relação ao Poder Legislativo, o que funciona como uma garantia ao sistema de freios e contrapesos inerente ao princípio da separação dos Poderes. Assim, caso o STF ultrapasse a permissão constitucional na edição de súmulas vinculantes, o Poder Legislativo poderá editar uma lei, visando justamente conter esses excesso do Poder Judiciário.

Desse modo, conforme os votos dos Ministros Sepúlveda Pertence e Joaquim Barbosa na Reclamação $\mathrm{n}^{\circ}$. 4335/AC, a edição de súmulas vinculantes seria uma opção constitucional para que as decisões do Supremo Tribunal Federal, em processos concretos, adquiram eficácia erga omnes e efeito vinculante, sem que haja violação da Constituição e do princípio da separação dos poderes. Nesse sentido, observa Glauco Salomão Leite: 
STF pode consolidar sua jurisprudência sobre a inconstitucionalidade de alguma norma, dotando-a de força obrigatória geral. ${ }^{93}$

Importante frisar que todo esse regime jurídico para que as decisões do Supremo Tribunal Federal possam ter efeitos jurídicos gerais e vinculantes foi introduzido por meio de uma Emenda Constitucional recente e, posteriormente, regulamentado por meio de uma lei, que estabelecem uma série de requisitos para sua elaboração, além da possibilidade de participação da sociedade no processo e da necessidade de uma publicação formal. Portanto, uma decisão do Supremo Tribunal Federal, em controle difuso de constitucionalidade, não pode adquirir efeitos vinculantes sem que todos esses requisitos sejam observados. São exigências constitucionais e legais recentes, que demonstram a real vontade do legislador.

\footnotetext{
${ }^{93}$ LEITE, Glauco Salomão. Op. cit., p. 19.
} 


\section{CONCLUSÃO}

No presente trabalho, procurei sempre demonstrar a importância do fenômeno da mutação constitucional, para que o texto constitucional esteja sempre adaptado às evoluções da sociedade. Normalmente, a própria Constituição já prevê mecanismos de reforma do seu texto, tendo em vista, justamente, essas modificações na sociedade. Entretanto, são mecanismos formais e burocráticos, que na prática constitucional, mostram-se insuficientes diante das constantes transformações da sociedade. Dessa forma, para que a Constituição se mantenha viva e reflita os anseios da sociedade, torna-se imprescindível a realização de mutações constitucionais.

Nesse contexto, as mutações constitucionais podem ser definidas como mudanças informais da Constituição, que produzem uma alteração no sentido, alcance ou significado do dispositivo, sem modificação formal do texto. Na prática, as modalidades mais observadas são a interpretação constitucional e os costumes constitucionais.

Todavia, a realização de mutações constitucionais não é absolutamente livre. A mutação deve refletir um anseio da sociedade, além de não poder contrariar o texto e o espírito da Constituição. Assim, uma modificação da Constituição que seja realizada sem a observância desses limites será considerada uma mutação inconstitucional e, portanto, não admitida no nosso ordenamento jurídico.

Os ministros Gilmar Mendes e Eros Grau, na Reclamação $\mathrm{n}^{\circ}$. 4335/AC sugerem uma verdadeira mutação inconstitucional, pois modifica o sistema de controle de constitucionalidade brasileiro e, ainda, viola dispositivo claro da Constituição.

O sistema de controle de constitucionalidade adotado pelo país é híbrido, combinando o controle de constitucionalidade concentrado/abstrato com o controle de constitucionalidade difuso/concreto. Dessa forma, os legitimados pela Constituição poderão levar a questão da constitucionalidade de lei ou ato normativo diretamente ao Supremo 
Tribunal Federal, como questão principal da ação, em um processo abstrato, cuja decisão produzirá efeito erga omnes e vinculante. Ou ainda, o controle da constitucionalidade da lei ou ato normativo poderá ser realizado como questão prejudicial em um processo concreto e, como a decisão a respeito da constitucionalidade da norma levará em conta as peculiaridades do caso concreto, somente produzirá efeito entre as partes litigantes.

Destaca-se que as constituições, desde 1934, contemplam a possibilidade do Senado Federal suspender a execução de lei ou ato normativo declarado inconstitucional, por decisão definitiva do Supremo Tribunal Federal, em controle incidental de constitucionalidade. Essa previsão reflete uma forma da decisão, que declara a inconstitucionalidade de uma norma em um caso concreto, adquirir eficácia erga omnes e vinculante.

Na referida proposta de mutação constitucional, os Ministros Gilmar Mendes e Eros Grau defendem que as decisões definitivas do Supremo Tribunal Federal, ainda que em sede de controle de constitucionalidade difuso/concreto, seriam dotadas de eficácia erga omnes e efeito vinculante. Argumentam que o artigo 52, X, da Constituição, que prevê a mencionada competência do Senado Federal, merece uma releitura, devendo ser interpretado no sentido de competir ao Senado apenas a publicação das leis ou atos normativos declarados inconstitucionais pelo STF.

Dentre os argumentos apresentados, destaca-se a prioridade que a Constituição Federal de 1988 atribui ao controle de constitucionalidade concentrado/abstrato com a ampliação de ações diretas e do rol dos legitimados para a sua propositura. Questiona-se também o caráter histórico/tradicional da competência do Senado que não faria sentido atualmente, e apontam inovações legislativas que já conferem efeito vinculante às decisões do STF.

Como ficou demonstrado, a mencionada mutação é inconstitucional. Além disso, os argumentos apresentados não procedem. A mesma Constituição que priorizou o controle difuso também manteve a 
competência do Senado, dai a intenção do poder constituinte originário em manter o controle de constitucionalidade híbrido no país. As mencionadas inovações legislativas que conferem certo efeito vinculante a decisões do STF apenas vinculam os próprios órgãos do Pode Judiciário, sem revelar uma afronta à Constituição, pois que a vinculação está dentro do próprio Poder. Totalmente diferente é essa proposta de abstrativização do controle difuso de constitucionalidade, em que um Poder (STF - Poder Judiciário) está querendo avocar competência que a própria Constituição atribui a outro Poder (Senado Federal - Poder Legislativo), o que configura flagrante afronta ao princípio da separação dos poderes.

Não concordo também com o argumento de que a competência do Senado teria perdido a razão de ser. Concordo que sua importância foi reduzida diante da multiplicação dos casos de controle de constitucionalidade concentrado/abstrato e diante da possibilidade de edição de súmulas vinculantes. Porém, o controle difuso e, conseqüentemente, a competência do Senado Federal possuem grande importância no nosso sistema, uma vez que leva em conta as peculiaridades do caso concreto e, exatamente por considerar essas especificidades de cada caso, que a decisão tem eficácia restrita às partes. Aqui não se trata de discutir teses jurídicas, e sim a decisão mais correta para o caso em questão, pois uma lei pode ser inconstitucional em um caso e não ser em outro.

Caso os votos dos Ministros Gilmar Mendes e Eros Grau tornem-se majoritários ocorrerá a abstrativização do controle difuso. Com isso, os juízes e tribunais perderão sua independência na análise da questão da inconstitucionalidade no caso concreto, pois que estarão sempre vinculados a uma decisão anterior do STF sobre a matéria, o que implica, em última análise, na petrificação dos significados jurídicos.

Na Reclamação nº 4335/AC, os Ministros Sepúlveda Pertence e Joaquim Barbosa proferiram votos em sentido contrário ao Exmº . Relator, Ministro Gilmar Mendes, rejeitando a sugerida mutação constitucional, por acreditarem na convivência paralela dos sistemas de controle de 
constitucionalidade. Como alternativa constitucional para a eficácia erga omnes e vinculante das decisões do STF, apontaram a edição de súmulas vinculantes.

Esta é a solução constitucional para as decisões do Supremo Tribunal Federal adquirirem eficácia erga omnes e efeito vinculante. Assim, deverão ser observados os requisitos constitucionais e legais, a saber, o quórum de dois terços para a aprovação, reiteradas decisões sobre a questão constitucional, a possibilidade de participação da sociedade no processo e a necessidade de uma publicação formal. Diante de todo esse regime jurídico para a edição de súmulas vinculantes, incorporado recentemente à Constituição por meio de emenda constitucional e, posteriormente, regulamentado por lei especial, não é sequer razoável admitir que uma decisão apertada do Supremo Tribunal Federal em controle de constitucionalidade difuso, ainda não amadurecida, que não observa esses requisitos, produza os mesmos efeitos, sem que haja qualquer previsão constitucional ou legal autorizando.

Em suma, a mutação constitucional é limitada pelo texto e espírito da Constituição. A proposta de mutação dos Ministros Gilmar Mendes e Eros Grau na Reclamação ${ }^{\circ}$. 4335/AC, não observa esses limites, configurando verdadeira mutação inconstitucional. De forma constitucional, o STF somente poderia conceder efeitos vinculantes e gerais às suas decisões por meio da edição de súmulas vinculantes, desde que observados os requisitos constitucionais e legais. 


\section{BIBLIOGRAFIA}

BARROSO, Luís Roberto. Interpretação e Aplicação da Constituição. $4^{\mathrm{a}}$ ed., rev., atual. e ampl. - São Paulo: Saraiva, 2001. 324 p.

- O controle de constitucionalidade no direito brasileiro: exposição sistemática da doutrina e análise crítica da jurisprudência. $3^{\mathrm{a}}$ edição, revista e atualizada. São Paulo: Saraiva, 2008. 359 p.

BINENBOJM, Gustavo. A Nova Jurisdição Constitucional Brasileira. Rio de Janeiro: Renovar, 2001. 260 p.

BONAVIDES, Paulo. Curso de Direito Constitucional. 14. Edição. São Paulo: Malheiros, 2004. 806 p.

BULOS, Uadi Lammêgo. Mutação Constitucional. São Paulo: Saraiva, 1997. $215 \mathrm{p}$.

- Constituição Federal anotada. 8 ${ }^{\mathrm{a}}$. ed. rev. e atual. até a Emenda Constitucional n. 56/2007 - São Paulo: Saraiva, 2008. 1596 p.

CASTRO, Flávia Viveiros de. O Princípio da Separação dos Poderes. In: PEXINHO, Manoel Messias; GUERRA, Isabella Franco; NASCIMENTO FILHO, Firly (Org.). Os princípios da Constituição de 1988. 2ª ed. Rio de Janeiro: Editora Lumem Juris, 2006. p. 133 - 145.

CLÉVE, Clèmerson Merlin. A Fiscalização Abstrata da Constitucionalidade no Direito Brasileiro. $2^{\mathrm{a}}$ ed., São Paulo: Revista dos Tribunais, 2000. 484 p. 
DALLARI, Dalmo de Abreu. Elementos de Teoria Geral do Estado. 24a. ed. - São Paulo: Saraiva, 2003. 307 p.

FERRAZ, Ana Cândida da Cunha. Processos informais de mudança da Constituição: mutações constitucionais e mutações inconstitucionais. São Paulo: Editora Max Limonad Ltda., 1986. 269 p.

LEITE, Fábio Carvalho. Revisão da doutrina dos limites ao poder de reforma na constituição de 1988 (reflexões a partir do estudo de dois casos). Direito, Estado e Sociedade: Revista do Departamento de Direito da PUCRio, Rio de Janeiro, no. 29, p. 87 - 151, jul/dez 2006.

. ADIN e ADC, e a Ambivalência Possível: Uma Proposta. 39 p. LEITE, Glauco Salomão. A extensão da eficácia erga omnes e do efeito vinculante às decisões de inconstitucionalidade em controle difuso pelo Supremo Tribunal Federal: hipótese de mutação (in)constitucional. Disponível em <http://www.ihj.org.br/pdfs/Artigo_Mutacao_Glauco.pdf>. Acesso em 01 de agosto de 2008. 20 p.

MENDES, Gilmar Ferreira; COELHO, Inocêncio Mártire; BRANCO, Paulo Gustavo Gonet. Curso de Direito Constitucional. $2^{\mathrm{a}}$ ed. rev. e atual. São Paulo: Saraiva, 2008. 1432 p.

MONTEZ, Marcus Vinícius Lopes. A abstrativização do controle difuso. In: Jus Navigandi, Teresina, ano 12, n. 1627, 15 dez. 2007. Disponível em: $<$ http://jus2.uol.com.br/doutrina/texto.asp?id=10711 >. Acesso em: 13 out. 2008.

MORAES, Alexandre de. Jurisdição Constitucional e Tribunais Constitucionais; garantia suprema da constituição. $2^{\mathrm{a}}$. ed. - São Paulo: Atlas, 2003. $342 \mathrm{p}$. 
. Direito Constitucional. 21 a edição. São Paulo: Atlas, 2007. 994

p.

OLIVEIRA, Maria Lúcia de Paula. Princípio da Separação dos Poderes e Jurisdição Constitucional: A Experiência Brasileira. In: PEXINHO, Manoel Messias; GUERRA, Isabella Franco; NASCIMENTO FILHO, Firly (Org.). Os Princípios da Constituição de 1988. 2a . ed. Rio de Janeiro: Editora Lumem Juris, 2006. p. 147 - 156.

PIÇARRA, Nuno. A Separação dos Poderes como doutrina e princípio constitucional: um contributo para o estudo das suas origens e evolução. Coimbra: Coimbra editora, 1989. 281 p.

SIFUENTES, Mônica. Súmula Vinculante: um estudo sobre o poder normativo dos tribunais. São Paulo: Saraiva, 2005. 326 p.

SILVA, José Afonso da. Curso de Direito Constitucional Positivo. 24a . ed. rev. e atual. São Paulo: Malheiros, 2005. 925 p.

STRECK, Lenio Luiz. Jurisdição Constitucional e Hermenêutica: uma nova crítica do direito. $2^{\mathrm{a}}$. ed. - Rio de Janeiro: Forense, 2004. 919 p.

; OLIVEIRA, Marcelo Andrade Cattoni de. A nova perspectiva do Supremo Tribunal Federal sobre o controle difuso: mutação constitucional e limites da legitimidade da jurisdição constitucional. In: Jus Navigandi, Teresina, ano 11, n. 1498, 8 ago. 2007. Disponível em: $<$ http://jus2.uol.com.br/doutrina/texto.asp?id=10253>. Acesso em: 28 ago. 2008. 
VECCHI, Cristiano Brandão. A mutação constitucional: uma abordagem

Alemã. Rio de Janeiro, 2005. Dissertação de Mestrado - Departamento de Direito, Pontifícia Universidade Católica do Rio de Janeiro. 148 p. 